\title{
Does Banking Competition Affect Innovation?
}

\author{
Jess Cornaggia \\ McDonough School of Business \\ Georgetown University \\ jc2394@georgetown.edu \\ (812) 856-4068
}

Xuan Tian

Kelley School of Business

Indiana University

tianx@indiana.edu

(812) 855-3420

\author{
Yifei Mao \\ Kelley School of Business \\ Indiana University \\ yifmao@indiana.edu \\ (812) 855-3476 \\ Brian Wolfe \\ Kelley School of Business \\ Indiana University \\ wolfeba@indiana.edu \\ (812) 369-5702
}

This Version: August 2013

\footnotetext{
* We thank an anonymous referee, Matthew Billett, Alexander Borisov, Michael Fuerst, Philip Strahan, Bill Schwert (the editor), Jason Sturgess, Krishnamurty Subramanian, Gregory Udell, and seminar and conference participants at Indiana University, the 2013 Western Finance Association meetings, and the 2012 Financial Management Association meetings for helpful comments. All errors belong to the authors.
} 


\title{
Does Banking Competition Affect Innovation?
}

\begin{abstract}
We exploit the deregulation of interstate bank branching laws to test whether banking competition affects innovation. We find robust evidence that banking competition reduces statelevel innovation by public corporations headquartered within deregulating states. Innovation increases among private firms that are dependent on external finance and that have limited access to credit from local banks. We argue that banking competition enables small, innovative firms to secure financing instead of being acquired by public corporations. Therefore, banking competition reduces the supply of innovative targets, which reduces the portion of state-level innovation attributable to public corporations. Overall, these results shed light on the real effects of banking competition and the determinants of innovation.
\end{abstract}

JEL classifications: G21, G28, G34, O16, O31

Keywords: Banking competition, Innovation, Access to finance, External finance dependence, Mergers and acquisitions, Economic growth 


\section{Introduction}

What drives innovation? Understanding the determinants of innovation is important because innovations establish companies' competitive advantages (Porter, 1992) and are important drivers of economic growth (Solow, 1957). A growing literature takes up this task, documenting positive and negative empirical links between innovation and various company and market characteristics. However, this literature contains few empirical studies examining the link between capital market development and innovation output. We contribute to this nascent literature by examining the effects of state-level banking competition on innovation.

A major challenge facing the empirical innovation literature is that innovation is likely endogenous with company and market characteristics, including state-level banking competition. Thus, a correlation between banking competition and innovation may tell us little about the causal effect of banking competition on innovation. We alleviate endogeneity concerns by exploiting the staggered deregulation of interstate bank branching laws in the United States. The U.S. Congress passed the Interstate Banking and Branching Efficiency Act (IBBEA) in 1994. In addition to allowing unrestricted interstate banking, the IBBEA legalized interstate branching across the U.S. starting in 1997. As Rice and Strahan (2010) explain, “Allowing interstate branching was the watershed event of IBBEA” (page 861). Rice and Strahan show that, when states relax bank branching restrictions, more bank branches open and compete with one another. This increase in competition expands the availability of credit within a state and lowers the cost of capital therein.

We construct tests using these deregulatory events as plausibly exogenous increases in the supply of state-level finance. Given the economic effects documented by Rice and Strahan (2010), we expect state-level innovation to increase following deregulation because companies headquartered within deregulating states could take advantage of the greater supply of finance to increase innovation output. Surprisingly, however, we find robust evidence that increases in banking competition cause states' innovation outputs to decline. We find that states that are completely open to interstate branching generate a total of 30.8\% fewer patents (i.e., 920 fewer patents) three years after branching deregulation than states with the most restrictions on interstate branching. We find a similar result when we use patent citations as a proxy for innovation: States that are completely open to interstate branching generate patents that receive a total of 23.2\% fewer citations (i.e., 9,068 fewer citations) three years after branching 
deregulation than states with the most restrictions on interstate branching. These results are robust to controlling for state-level and state-industry-level labor force concentration, banking deregulatory events that precede IBBEA, state fixed effects, and year fixed effects.

To gain a clearer understanding of this result, we decompose state-level patents into patents produced by public corporations and private firms. ${ }^{1}$ Private firms could be more sensitive to local banking conditions than public corporations, so the effects of state-level banking competition could be different for these two groups. Indeed, we find the overall negative effect of deregulatory events on state-level innovation is driven by corporations headquartered within deregulating states. In contrast, relative to corporations, private firms experience increases in innovation output following deregulatory events. (We find no direct effect of deregulation on private firms' innovation outputs.) These findings support the notion that small, private firms take advantage of the improved credit conditions to finance innovative projects.

Although the staggered deregulation of interstate bank branching laws provide exogenous changes to banking competition, Kroszner and Strahan (1999) argue that state-level factors that manifest differently across states could have affected the timing of deregulation in different states. Therefore, it is possible that our results are driven by reverse causality, whereby differences in innovation intensities across states triggered deregulation. We employ the methodology of Bertrand and Mullainathan (2003) to address this concern. We examine the dynamics of innovation surrounding the deregulatory events and we find no prior trend in innovation output. This finding indicates reverse causality does not explain our main results.

Another potential explanation for our results is that an omitted variable coinciding with branching deregulation could be the true underlying cause of changes in innovation. If this is the case, then the changes in innovation we attribute to branching deregulation reflect mere associations rather than a causal effect. Our baseline identification strategy employs shocks that affect different states at different times. It is unlikely that an omitted variable unrelated to branching deregulation would fluctuate every time (or even most of the times) a deregulatory event occurs. Therefore, our strategy of using multiple shocks due to staggered banking deregulation across states mitigates the omitted variables concern.

\footnotetext{
${ }^{1}$ To aid in distinction, we use the word "corporation" throughout the remainder of the paper to designate Compustat reported entities. We reserve the word "firm" for private firms whose stocks are not listed on stock exchanges. We use the word "company" as a general term for either public corporations or private firms.
} 
Still, we address this possibility by conducting placebo tests. We begin by obtaining an empirical distribution of years when states deregulated from Rice and Strahan (2010). Next, we randomly assign states into each of these deregulation years (without replacement) following the empirical distribution. This approach maintains the distribution of deregulatory years from our baseline specification, but it disrupts the proper assignment of deregulation years to states. Therefore, if an unobservable shock occurs at approximately the same time as the deregulation events in the mid-1990s, it should still reside in the testing framework, and thus have an opportunity to drive the results. However, if no such shock exists, then our incorrect assignments of deregulatory years to states should weaken our results when we re-estimate the baseline tests. Indeed, we find these falsely assumed deregulatory events have no effect on innovation. These non-results corroborate the notion that the paper's main results are not driven by an omitted variable.

After demonstrating that there is an aggregate decrease in patents and patent citations following increased banking competition from the IBBEA, we examine three possible channels to explain this result. First, we test whether companies' external finance dependence affects the way their innovation outputs respond to changes in state-level banking competition. We expect that banking competition relaxes financing constraints for private firms, mainly in externalfinance-dependent industries. Therefore, these private firms should experience increases in innovation output. This is precisely what we find. We use the measure of external finance dependence developed by Duchin, Ozbas, and Sensoy (2010) and find external-financedependent private firms located in states that are completely open to interstate branching generate a total of $7.6 \%$ more patents and $6.4 \%$ more citations three years after branching deregulation than firms in states with the most restrictions on interstate branching. This result is robust to a variety of alternative proxies for external finance dependence. We partition the data by company size, age, bank dependence following Acharya, Imbs and Sturgess (2011) and by the SA index following Hadlock and Pierce (2010), and we observe qualitatively similar results. In contrast, we observe no effect or a negative effect of banking deregulation on private firms with below-median dependence on external finance.

Second, companies' banking relationships prior to deregulatory events provide another way to test how the need for external finance interacts with changes in banking competition. As banking competition increases, we expect the innovation output of companies with existing loans 
from in-state banks to react differently compared to companies with loans from out-of-state banks. We hypothesize that in-state banking relationships are evidence that companies are able to satisfy their demand for external finance from nearby banks. However, if companies borrow from out-of-state banks, it indicates that they are unable to satisfy their demand for finance from nearby banks. If banking competition expands access to finance, and if companies use it to finance innovative projects, then the innovation output of the latter group of companies should increase following increases in banking competition. Indeed, we observe an increase in the innovation output of private firms with high pre-existing out-of-state bank loans after deregulatory events and no change in the innovation output of public corporations and private firms with prior in-state banking relationships. Like the external finance dependence results, these results provide evidence that companies that are most likely to benefit from expanded access to bank finance take advantage of state-level banking competition to improve their innovative output.

Finally, we test a mergers and acquisitions (M\&A) based explanation for the negative effect of branching deregulation on corporate innovation. Because proximal banking conditions matter for small firms (Petersen and Rajan, 2002), changes in state-level banking competition could alter the market for target firms in corporations' headquarter states. ${ }^{2}$ Given foundermanagers' private benefits of control, the owners of small firms prefer to secure financing while giving away as little control as possible to the financiers (Bolton and Von Thadden, 1998). On the other hand, Erel, Jang, and Weisbach (2013) find that M\&As significantly ease financial constraints of target firms and Sevilir and Tian (2012) show that a significant portion of corporations' innovation output derives from acquisitions of innovative targets. Together, these papers suggest that increases in state-level banking competition could allow small, innovative firms to secure bank financing to fund innovative projects and remain independent instead of being acquired by corporations. This effect could lead to a dearth of willing targets which would generate a reduction in corporate innovation.

Consistent with our conjecture that corporations' abilities to acquire small, innovative target firms are impaired after bank branching deregulation, we find the overall negative effects of banking competition on innovation are particularly strong among corporations that are

\footnotetext{
2 We document the largest proportion of acquiring firms' targets reside in the acquiring firms' headquarter states (i.e., 22 percent).
} 
frequent acquirers and have high M\&A expenditures before deregulatory events. Further, for a given corporation, we find the average innovativeness of the targets it acquires declines after banking competition increases in its headquarter state. This result indicates that the pool of potential targets within a state contains less innovative firms after deregulation. Finally, we find the ratio of target firms that produce at least one patent in a year to total private firms located within a state declines after banking competition increases. All of these results suggest that a reduction in the supply of innovative targets is a possible mechanism that helps explain the overall negative relation between state-level banking competition and corporate innovation. Further, the finding that target firms seek bank financing after deregulation supports the view that banking was repressed in the United States until branching deregulation was enacted.

The rest of the paper proceeds as follows. Section 2 describes how this paper relates to existing literature. Section 3 describes the data and variable construction. Section 4 presents the baseline results and endogeneity tests. Section 5 discusses the underlying mechanisms of our baseline results and Section 6 concludes.

\section{Relation to existing literature}

Our paper contributes to two strands of literature. First, our paper is related to the literature that examines the real effects of banking deregulation. This literature begins with Jayaratne and Strahan (1996), who show intrastate branching deregulation significantly increases the rates of real per capita growth in income and output. Following this study, a large literature has examined various consequences of the intrastate branching and interstate banking deregulation events that occurred in the U.S. in the 1970s and 1980s. These studies find that deregulation spurs entrepreneurship (Black and Strahan, 2002), makes state business cycles smaller and more alike (Morgan, Rime, and Strahan, 2004), allows firm entry and access to bank credit (Caterelli and Strahan, 2006), promotes creative destruction (Kerr and Nanda, 2009), and increases personal bankruptcy rates (Dick and Lehnert, 2010). Rice and Strahan (2010) show that the interstate branching deregulation that occurred in the U.S. in the mid-1990s expands credit supply by reducing the cost of credit but has no effect on the amount borrowed by small firms. We examine the effects of the same deregulatory event as Rice and Strahan (2010). We advance this line of inquiry by showing that the reduced cost of credit allows private, external-financedependent firms to secure bank financing to fund innovative projects. 
Second, our paper contributes to the emerging literature on finance and innovation. This literature shows relations between innovation and market characteristics including competition (Aghion et al., 2005), bankruptcy laws (Acharya and Subramanian, 2009), labor laws (Acharya, Baghai, and Subramanian, 2011, 2012), and investors' attitudes toward failure (Tian and Wang, 2012), as well as firm characteristics including corporate governance (Meulbroek et al., 1990), stock liquidity (Fang, Tian, and Tice, 2013), firm boundaries (Seru, 2012), analyst coverage (He and Tian, 2013), and institutional ownership (Aghion, Van Reenen, and Zingales, 2013). Few empirical studies examine the link between capital market development and firm innovation. Benfratello, Schiantarelli, and Sembenelli (2008) show that local banking development increases the "process innovation" (but not necessarily the "product innovation") of Italian manufacturing firms. Hsu, Tian, and Xu (2013) find that industries that are more dependent on external finance and that are more high-tech intensive exhibit a higher innovation level in countries with better developed equity market, but the development of credit market appears to discourage innovation in industries with these characteristics, using a sample of 32 developed and emerging countries.

Our study is related to three contemporaneous papers. Amore, Schneider, and Zaldokas (2013) find that interstate banking deregulation in the 1980s has a positive effect on the innovative performance of public corporations. Chava et al. (2013) show contrasting effects of intrastate branching and interstate banking deregulation on innovation by private firms. These authors find that interstate banking deregulation increases innovation by young, private firms but intrastate branching deregulation decreases innovation by these firms. Hombert and Matray (2013) examine the same deregulatory events as the above two papers and find the number of innovators decreases after these two deregulatory events. Unlike these three studies that examine the effects of deregulatory events that occurred in the 1970s and 1980s, we focus on the effects of interstate branching deregulation which occurred in the mid-1990s. We find that interstate branching deregulation caused a decrease in the innovation output of corporations, but an increase in the innovation output of external-finance-dependent private firms. We also show that declined acquisition of small, innovative firms by public corporations is an underlying mechanism that drives the reduction in corporate innovation post deregulation.

\section{Sample selection and summary statistics}

\subsection{Sample selection}


The sample includes U.S. listed corporations and private firms during the period of 1976 to 2006. We compile our data set from several databases. We collect annual patent and citation information from the latest version of the National Bureau of Economic Research (NBER) Patent Citation database. We obtain merger and acquisition (M\&A) information from the Security Data Company (SDC) M\&A database, bank loan data from the Thomson Reuters DealScan database, and the number of private non-farm businesses from the U.S. Census Bureau. To construct corporation-level control variables, we collect financial statement items from Compustat Industrial Annual Files.

\subsection{Variable measurement}

\subsubsection{Measuring innovation}

We construct the innovation variables from the latest version of the NBER Patent Citation database initially created by Hall, Jaffe, and Trajtenberg (2001). The database provides detailed information on more than three million patents granted by the USPTO from 1976 to 2006. The patent database provides annual information on patent assignee (owner) names, the number of patents, the number of citations received by each patent, a patent's 3-digit technology class, a patent's application year, and a patent's grant year.

Based on the information available in the NBER database, we construct two measures for a company-year's innovation output. The first measure is a company's number of patent applications filed in a year that are eventually granted. ${ }^{3}$ Although straightforward to compute, this measure cannot distinguish groundbreaking innovations from incremental discoveries. To further assess a patent's influence, we construct a second measure of company innovation output by counting the number of citations the companies' patents receive in subsequent years. Hence, the number of patents captures the quantity of innovation output while the number of citations captures the importance and quality of innovation output. ${ }^{4}$ To reflect the long-term nature of investment in innovation, we consider the total innovation output generated in the next three years in the future. This approach mitigates the influence of idiosyncratic shocks that could distort innovation output in any particular year.

\footnotetext{
${ }^{3}$ We use a patent's application year instead of its grant year because the application year better captures the actual time of innovation (Griliches, Pakes, and Hall, 1988).

${ }^{4}$ For robustness, we exclude self-citations when counting the number of citations. We find qualitatively similar results to those throughout the paper.
} 
Following the existing innovation literature, we adjust the innovation output measures to address two types of truncation problems associated with the NBER database. The first truncation problem arises as patents appear in the database only after they are granted. In fact, we observe a gradual decrease in the number of patent applications that are eventually granted as we approach the last few years in the sample period (i.e., 2005 and 2006). This truncation occurs because the lag between a patent's application year and its grant year is significant (about two years on average) and many patent applications filed during these years were still under review and had not been granted by 2006. To adjust the truncation bias in patent counts, following Hall, Jaffe, and Trajtenberg (2001), we adjust patent counts using the "weight factors" computed from the application-grant empirical distribution. The second type of truncation problem is regarding the citation counts, because patents keep receiving citations over a long period of time, but we observe at beast only the citation received up to 2006. Following Hall, Jaffe, and Trajtenberg (2001), we correct for the truncation in citation counts by estimating the shape of the citation-lag distribution.

To gauge public corporations' innovation productivity, we merge the NBER patent data with the Compustat firm sample using a bridge file provided by the NBER database in which GVKEY is the common identifier. For cases in which the corporate headquarter is different than the assignee state, we use the headquarter state of the corporation. To measure private firms' innovation output, we classify a firm as private if it does not have a GVKEY and therefore cannot be matched with the Compustat database. We cross check this information with the United States Patent and Trademark Office (USPTO) (available at http://www.uspto.gov/) and exclude assignees that are either governments, universities, or individuals. Following the innovation literature, we set the number of patents to zero for companies that have no patent information available from the NBER database.

In the baseline analysis, we aggregate patents generated by corporations and firms to the state level and our tests are based on state-year observations. In later tests in which we examine the economic mechanisms underlying the baseline analysis, we conduct tests at the company level. The distribution of patent grants in the sample is right skewed. Therefore, we use the natural logarithm of the total number of weight-factor adjusted patent counts and the natural logarithm of the citation-lag adjusted citations for patents generated in the subsequent three years, LnPat and LnCite, as the main innovation measures in our analysis. To avoid losing 
observations with zero patents or zero citations, we add one to the actual values when calculating the natural logarithm.

\subsubsection{Measuring banking competition and control variables}

We follow Rice and Strahan (2010) to construct an index of interstate branching restrictions, RSindex. As described in Rice and Strahan (2010), the Interstate Banking and Branching Efficiency Act (IBBEA) allowed states to employ a variety of means to erect out-ofstate entry barriers from the time of enactment in 1994 until the branching trigger date of June 1, 1997. Specifically, states could set regulations on interstate branching with regard to four provisions: (i), the minimum age of the target institution; (ii), de novo interstate branching; (iii), the acquisition of individual branches; and (iv) a statewide deposit cap. When a state adds any of the above four barriers, we add one to the RSindex. Therefore, the RSindex ranges from zero to four with zero indicating the most open stance toward interstate entry and four indicating the most restrictive stance toward interstate entry. See Rice and Strahan (2010) for a detailed discussion on the institutional background and construction of the index.

In our baseline state-level analysis, we follow Morgan, Rime, and Strahan (2004) and compute the state-level labor force composition for eight different industry segments: Mining, Construction, Manufacturing, Transportation, Trade, Finance, Service, and Government. We include these measures in the baseline analysis. We also control for state-level labor force concentration and nominal gross product. To control for the effects of other banking deregulatory events which occurred early in our sample period (i.e., the 1970s and 1980s), we construct two dummy variables: Intra that equals zero the years before the focal state pursued intrastate branching deregulation and one otherwise (Jayaratne and Strahan, 1996), and Inter that equals zero the years before the focal state pursued interstate banking deregulation and one otherwise (Black and Strahan, 2002).

We conduct tests with corporation-year level data later in the paper to better understand the mechanisms underlying our baseline findings. In this analysis, we control for a vector of corporation and industry characteristics that may affect a corporation's future innovation output. Following the innovation literature, we compute all variables for corporation $i$ over its fiscal year t. Control variables include investments in intangible assets $(\mathrm{R} \& \mathrm{D}$ expenditures divided by total assets), profitability (ROA), asset tangibility (net PPE divided by total assets), leverage, capital 
expenditures (capital expenditures divided by total assets), industry concentration (Herfindahl Index based on sales), growth opportunities (Tobin's $Q$ ), corporation size (the natural logarithm of book value assets), and corporation age. To mitigate non-linear effects of product market competition on innovation output (Aghion et al., 2005), we include the squared Herfindahl Index in our baseline regressions. To minimize the effect of outliers, we winsorize all variables that have the potential to be unbounded at the $1^{\text {st }}$ and $99^{\text {th }}$ percentiles of their empirical distributions.

\subsection{Summary statistics}

Table 1 provides summary statistics of the variables used in this study. Panel A provides information in the aggregate state-year level. On average, a state in our sample has 2,988 granted patents in the subsequent three years and these patents receive a total of 39,085 citations. Among them, 1,962 patents are generated by public corporations and 1,026 patents are produced by private firms. The average value of RSindex is 3.5 in the pooled sample. In Panels B and C, we separately report descriptive statistics for public corporations and private firms, respectively. As reported in Panel B, at the corporation-year level, an average corporation generates 5 patents and 58 citations over three years, has an external finance dependence (EFD) value of -0.27 , has an R\&D-to-assets ratio of $4 \%$, ROA of $2 \%$, PPE-to-assets ratio of $32 \%$, leverage of $31 \%$, capital expenditure-to-assets ratio of 7\%, Tobin's $Q$ of 2.1, book value assets of $\$ 1.02$ billion, and is 20 years old since its founding date. Panel C reports summary statistics for private firms. At the firm-year level, an average firm generates 0.7 patent and 7 citations per year, has an EFD value of -0.31 , borrows $\$ 0.04$ million from in-state lenders, and borrows $\$ 0.36$ million from out-ofstate lenders.

\section{[Insert Table 1 here.]}

Fig. 1 displays the time series of the total number of patents in the aggregate state-level produced by all companies across all states, by public corporations only, and by private firms only. We show that the aggregate level of patents has steadily increased since 1976. Although public corporations always generate more patents than private firms, the fraction of patents produced by public corporations appears to decline relative to those produced by private firms towards the end of the sample when the interstate branching deregulation took place.

[Insert Fig. 1 here.] 


\section{Empirical results}

\subsection{Baseline specification and results}

As we discussed in the introduction, a major challenge of our study is the identification of the causal effects of banking competition on innovation, due to both omitted variables and reverse causality concerns. First, unobservable industry or state characteristics related to both local banking competition and innovation could remain in the residual term of regressions. These unobservable characteristics make it difficult to draw correct statistical inferences from standard OLS regressions. Second, there is an old debate on the direction of causality between finance and economic growth. (See Butler and Cornaggia (2011) for a recent review of this literature.) A large literature starting from Schumpeter (1911) argues that finance leads to economic growth (innovation is an important driver of economic growth (Solow, 1957)), while another large literature follows Robinson (1952) who famously argues that "where enterprise leads finance follows" (page 86). Our identification strategy is to exploit the staggered deregulation of interstate bank branching laws in the U.S., which generate plausibly exogenous variation in states' banking competition environments, following Rice and Strahan (2010). One key advantage of this identification strategy is that there are multiple shocks that affect different states at different times, which allows us to overcome a common difficulty facing studies with a single shock: the potential existence of omitted variables coinciding with the shock that affect economic outcomes (innovation, in our case).

Specifically, to assess how banking competition affects innovation, we estimate the following model:

$$
\text { LnPat }_{i, t+1 \text { to } t+3}=\alpha+\beta \text { SSindex }_{i, t}+\gamma Z_{i, t}+\text { Year }_{t}+\text { State }_{i}+\varepsilon_{i, t}
$$

where $i$ indexes state and $t$ indexes time. The dependent variable in Eq. (1a) is the natural logarithm of the total number of patents generated in a state in the following three years. We measure the banking competition variable, RSindex, for state $i$ in year $t . Z$ is a vector of controls that includes state-level labor force composition for eight different industry segments, labor force concentration, gross product, and dummies for other early banking deregulatory events. Year and $S t a t e_{i}$ capture year and state fixed effects, respectively. We cluster standard errors by year in our baseline tests.

We include state fixed effects in the baseline regression. This approach addresses the concern that unobservable variables omitted from Eq. (1a) that generate variation in a state's 
stance toward openness to interstate branching might be correlated with innovativeness, rendering our findings spurious. For example, if states with vibrant economic activities and strong growth opportunities are more likely to deregulate, then the state-level economic activities and growth opportunities are unobservables that correlate with both innovativeness and RSindex, which could bias our coefficient estimate of RSindex downward. Including state fixed effects will strip out any persistent differences across states. We report the OLS regression results estimating Eq. (1a) in column (1) of Table 2 Panel A.

\section{[Insert Table 2 here.]}

The coefficient estimates of RSindex are positive and significant at the $1 \%$ level. This finding suggests that an increase in banking competition due to deregulation (i.e., a decrease in RSindex) leads to a decrease in the number of patents in the first three subsequent years. To be more concrete, based on the coefficient estimate of RSindex in column (1), states that are completely open to interstate branching generated a total of $30.8 \%(=4 \times 0.077)$ fewer patents in the subsequent three years post branching deregulation than states with the most restrictions on interstate branching three years after deregulation.

The effect of banking competition on patent quantity is large: The above reduction translates to a drop of 920 patents over the three years after a deregulatory event. (Table 1 Panel A shows the average number of patents produced in a state over the three years after a deregulatory event is 2,988. The product of 2,988 and $30.8 \%$ is 920 .) This reduction in patent quantity is also large relative to the variability of patent production over time. We make this comparison by taking the average of state-level patent production in each of the 31 years of our sample. The standard deviation of these 31 observations is 449 patents. Therefore, because a reduction of 920 patents per state over three years implies a reduction of 307 patents per stateyear, this comparison shows that the reduction in patent quantity as a result of branching deregulation is equal to $68.4 \%$ of the variability of patent production over time. (The quotient of 307 patents and 449 patents is $68.4 \%$.) ${ }^{5}$

Although our evidence in column (1) suggests that branching deregulation adversely affects innovation by companies headquartered in the state, the negative effect could be different

\footnotetext{
${ }^{5}$ In an untabulated analysis, we examine the effect of banking deregulation on the number of patents generated in individual years (i.e., one, two, and three years) after deregulation. Consistent with our results in Table 2 Panel A, we find that an increase in banking competition due to deregulation leads to a decrease in the number of patents in each of the first three subsequent years.
} 
for public corporations and private firms. In particular, private firms could be more sensitive to local banking conditions than public corporations. In the next two columns, we separate patents generated by public corporations and those generated by private firms to examine whether banking competition affects innovation by these two types of companies differently. We estimate Eq. (1a) separately for public corporations and private firms and report regression results in columns (2) and (3), respectively. The coefficient estimate of RSindex in the sample of patents generated by public corporations is positive and significant at the $1 \%$ level, while that in the sample of patents produced by private firms is not statistically significant. The evidence suggests that the negative effect of banking competition due to deregulation on patent counts is driven by public corporations. This test uncovers no effect of deregulation on patent quantity of private firms. $^{6}$

Next, we examine the effect of banking competition on patent quality by replacing the dependent variable with our innovation quality proxy, the natural logarithm of patent citations, and estimate the following model:

$$
\text { LnCite }_{i, t+1} \text { to } t+3=\alpha+\beta \text { RSindex }_{i, t}+\gamma Z_{i, t}+\text { Year }_{t}+\text { State }_{i}+\varepsilon_{i, t}
$$

We report the results in columns (4) - (6). These tests parallel the first three columns in Panel A. In column (4), we find that the coefficient estimate of RSindex is positive and significant at the $1 \%$ level, suggesting that an increase in banking competition due to deregulation results in a decrease in the quality of patents generated by the companies headquartered in the state in the subsequent three years. To gauge the economic significance, based on the coefficient estimate of RSindex in column (4), states that are completely open to interstate branching generated a total of $23.2 \%(=4 \times 0.058)$ fewer citations for patents generated in the subsequent three years post branching deregulation than states with the most restrictions on interstate branching three years after deregulation.

The effect of banking competition on patent quality is large: The above reduction translates to a drop of 9,068 citations per state for patents generated over the three years after a deregulatory event. (Table 1 Panel A shows the average number of citations on patents produced in a state over the three years after a deregulatory event is 39,085. The product of 39,085 and

\footnotetext{
${ }^{6}$ In an untabulated analysis, we further explore the different effects of deregulation on innovation by public corporations and private firms by replacing the dependent variable with the raw difference between the number of patents produced by these two types of companies as well as the ratio of patents produced by these two types of companies. We find that the gap in patent output between public corporations and private firms decreases in the three years following deregulation.
} 
$23.2 \%$ is 9,068 .) This reduction in patent quality is also large relative to the variability of patent citations over time. We make this comparison by taking the average of citations on state-level patents in each of the 31 years of our sample. The standard deviation of these 31 observations is 8,486 citations. Therefore, because a reduction of 9,086 patent citations over three years implies a reduction of 3,022 citations per state-year, this comparison shows that the reduction in patent quality as a result of branching deregulation is equal to $35.6 \%$ of the variability of patent citations over time. (The quotient of 3,022 citations and 8,486 citations is $35.6 \%$.)

In the next two columns, we once again separate patents generated by public corporations and those generated by private firms and estimate Eq. (1b) to evaluate whether banking competition affects patent quality by these two types of firms differently. We continue to observe a positive and significant coefficient estimate of RSindex in the sample of patents generated by public corporations but an insignificant estimate of RSindex in the sample of patents generated by private firms. Consistent with our findings from patent counts, the evidence suggests that the negative effect of banking competition on patent quality is driven by public corporations.

Although a larger number of patent citations are typically interpreted as the patent having greater impact, the distribution of citations is also important. Hence, we construct two more patent-based measures, patent originality and generality, following Hall, Jaffe, and Trajtenberg (2005). We then examine the effect of banking competition on these two measures that capture the underlying nature of innovation being patented. Patents that cite a wider array of technology classes of patents are viewed as having greater originality. We define a patent's originality score as one minus the Herfindahl index of the three-digit technology class distribution of all the patents it cites. Therefore, the higher a patent's originality score, the more the patent draws upon a diverse array of existing knowledge. In a similar spirit, patents being cited by a wider array of technology classes of patents are considered as having greater generality. We define a patent's generality score as one minus the Herfindahl index of the three-digit technology class distribution of all the patens that cite it. The higher a patent's generality score, the more that the patent is being draw upon by a more diverse array of subsequent patents. We then average the individual patents' originality and generality scores at the state level. For states that generate no patents in a year, their patents generality and originality scores are undefined and therefore treated as missing. 
We replace the dependent variable with patent originality and generality in Eq. (1a) and report the regression results in Panel B. Like before, we evaluate the effect of banking competition on patent originality and generality generated by both types of companies, by public corporations only, and by private firms only in columns (1) - (3) and columns (4) - (6), respectively. The coefficient estimates of RSindex are statistically insignificant in all columns, suggesting that while banking deregulation negatively affects patent quantity and quality as we documented before, it does not directly affect the underlying nature of innovation being patented. $^{7}$ Therefore, in the rest of the paper, we focus on the analyses that examine the effect of banking competition on innovation quantity and quality measured by patent counts and citations.

We undertake a rich set of robustness tests for our baseline results and discuss the details of these tests in the Internet Appendix. We find that our baseline results are robust to alternative ways of clustering standard errors, alternative econometric models that address the certain features of innovation variables (i.e., right skewed, non-negative discrete variable), alternative subsamples, and several specifications designed to rule out reverse causality concerns arising from companies' decisions on where to establish or relocate their headquarters. Overall, our baseline results suggest that an exogenous increase in banking competition due to staggered interstate branching deregulation results in a lower state-level innovation output in subsequent years. This reduction in innovation output is driven by public corporations.

\subsection{Additional endogeneity tests}

As discussed above, although the staggered deregulation of interstate branching laws in the U.S. represents an exogenous shock to banking competition, Kroszner and Strahan (1999) argue that state-level factors that manifest differently across states could have affected the timing of deregulation in different states. A reverse causality concern may arise if the states also differ in their innovation intensities and such differences triggered the deregulation. Our robustness tests reported in the Internet Appendix mitigate such concerns. Specifically, we restrict our statelevel analysis to patents produced by corporations that do not relocate their headquarter any time during the sample period or corporations that are headquartered within a state at least three years before any changes in bank branching laws and find robust results. To further explore the

\footnotetext{
${ }^{7}$ Because both patent originality and generality scores are bounded between 0 and 1, we use a Tobit model and find qualitatively similar results.
} 
possibility of reverse causality, we follow Bertrand and Mullainathan (2003) to examine the dynamics of innovation surrounding deregulatory events. If reserve causality is indeed present, we should observe changes in innovation prior to deregulatory events.

To check the pre-existing trends in innovation, we restrict our sample to a 21-year window surrounding state-deregulation years (10 years before and 10 years after). We decompose each of the four components of the RSindex into four dummy variables associated with four periods around the deregulation year: all years up to and including two years prior to deregulation, one year prior to deregulation, one year post deregulation, and two years or more post deregulation. We then sum over the four components of the RSindex to obtain four new variables, Before ${ }^{2+}$, Before ${ }^{l}$, After ${ }^{l}$, and After $^{2+}$, corresponding to the four time periods around each deregulation. The deregulation year is the reference year in this setting. The coefficient estimates of Before ${ }^{2+}$ and Before ${ }^{l}$ are especially important because their significance and magnitude would indicate whether there is any relation between innovation and deregulatory events before interstate branching laws were changed. We estimate the following model:

$$
\text { LnPat }_{i, t}\left(\text { LnCite }_{i, t}\right)=\alpha+\beta_{1} \text { Before }_{i, e}{ }^{2+}+\beta_{2} \text { Before }_{i, t}{ }^{1}+\beta_{3} \text { After }_{i, t}{ }^{1}+\beta_{4} \text { After }_{i, t}{ }^{2+}+\text { Year }_{t}+
$$

State $_{i}+\varepsilon_{i, t}$

where $i$ indexes state and $t$ indexes time.

In Table 3 we report the regression results estimating Eq. (2). In column (1), we report the results for patents generated by both public corporations and private firms. The coefficient estimates of Before ${ }^{2+}$ and Before ${ }^{l}$ are not significant, suggesting that state-level innovation shows no significant change prior to interstate branching deregulation. The coefficient estimates of After $^{1}$ and After $^{2+}$ are negative and significant, consistent with our baseline findings. In column (2), we focus on patents generated by public corporations and find similar results: The coefficient estimates of Before ${ }^{2+}$ and Before ${ }^{1}$ are not significant while those of After $^{l}$ and After $^{2+}$ are negative and significant. We report results for patents generated by private firms in column (3). None of Before ${ }^{2+}$, Before ${ }^{l}$, After $^{l}$, and After $^{2+}$ is statistically significant. This non-result indicates trends in innovation by private firms do not reverse-cause branching deregulation. In columns (4) - (6), we repeat these tests with patent citations as the dependent variable and we observe a similar pattern around the deregulation year. The evidence for patent citations is slightly weaker than what we find for patent production, but the results show that patent citations decline only after branching deregulation. Overall, the results presented in Table 3 suggest that, 
whether we consider all companies, or public corporations and private firms separately, there is not a pre-existing trend in innovation before interstate branching deregulation. These results mitigate concerns about reverse causality.

Another concern that prevents us drawing a causal interpretation of banking competition on innovation from our baseline regressions is an omitted variables problem: Unobservable shocks or variables that are omitted from our analysis but coincide with state-level deregulatory events could drive our results. To address this concern, we conduct placebo tests to check whether our results disappear when we artificially (i.e., incorrectly) assume the deregulation occur in years other than the actual deregulation year. We do this by first obtaining an empirical distribution of years when states deregulated from Rice and Strahan (2010). We then randomly assign states into each of these deregulation years (without replacement) following the empirical distribution. This approach maintains the distribution of deregulatory years from our baseline specification, but it disrupts the proper assignment of deregulation years to states. Therefore, if

an unobservable shock occurs at approximately the same time as the deregulation events in the mid-1990s, it should still reside in the testing framework, and thus have an opportunity to drive the results. However, if no such shock exists, then our incorrect assignments of deregulatory years to states should weaken our results when we re-estimate our baseline regressions in Eqs. (1a) and (1b). We report the results in Table 4. The coefficient estimates of RSindex are statistically insignificant and not different from zero in all columns.

[Insert Table 4 here.]

Overall, the various tests for reverse causality and omitted variables reported in this subsection support the notion that banking competition due to deregulation appears to have a causal, negative effect on state-level innovation output, which is mainly driven by public corporations.

\section{Mechanisms}

Our evidence so far shows a robust, negative effect of state-level banking competition on innovation by public corporations, which does not appear to be driven by a pre-existing trend in innovation output prior to deregulation nor omitted shocks coinciding with the deregulation. However, our tests reveal no effect of banking competition on innovation by private firms. In this section, we explore possible underlying mechanisms through which banking competition 
may affect companies' innovation output. Specifically, we examine whether external finance dependence, prior banking relationships, and acquisitions of private, innovative firms by public corporations are possible underlying economic mechanisms through which banking competition affects innovation. To facilitate the exploration of mechanisms, we expand the state-year sample used in the baseline tests in Section 4 to corporation-year and private firm-year samples in this section. To save space, we suppress the coefficient estimates of all controls in the tables reported in this section.

\subsection{External finance dependence}

Although we show banking competition has a negative effect on public corporations' innovation and has no effect on private firms' innovation, the reduced cost of capital within states due to bank branching deregulation (Rice and Strahan, 2010) may still relax financing constraints for these firms. Therefore, it is possible that public corporations as well as private firms that are in external-finance-dependent industries could take advantage of state-level banking competition to improve their innovative output. In this section, we examine whether companies’ dependence on external finance is an underlying mechanism.

If banking competition directly affects the access to credit of corporations and firms, which increases their innovativeness as suggested by the literature showing finance creates growth, we expect that corporations and firms that are external-finance-dependent should have an increase, instead of a decrease, in innovation output after banking competition increases. Using the measure of external finance dependence developed by Duchin, Ozbas, and Sensoy

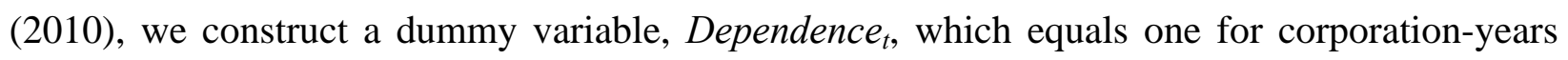
below the industry median external finance dependence (EFD) value (i.e., less external-financedependent) and zero for corporation-years above the industry median external finance dependence value (i.e., more external-finance-dependent). To capture private firms' external finance dependence, we first define a private firm's industry membership based on the technology classifications of patents which it files. We use a mapping file provided by Brian Silverman (available at http://www-2.rotman.utoronto.ca/ silverman/ipcsic/documentation_IPCSIC_concordance.htm) which links the International Patent Code (IPC) assigned to each patent by USPTO to a distribution of 3-digit SIC codes. We then impute EFD numbers from public corporations in industry $j$ in year $t$ to private firms in the same industry and year. For each 
private firm-year, we then compute the average EFD and carry this value forward for private firm-years in which no patents are generated. Similarly, we construct a dummy variable, Dependence $_{t}$, for private firms, which equals one for firm-years below the industry median EFD value and zero for firm-years above the industry median external finance dependence value.

To examine how a company's external finance dependence alters the marginal impact of banking competition on its innovation output, we estimate the following model:

$$
\text { LnPat }_{i, t+1} \text { to t+3 }\left(\text { LnCite }_{i, t+1} \text { to }{ }_{t+3}\right)=\alpha+\beta_{1} \text { RSindex }_{k, t}+\beta_{2} \text { Dependence }_{i, t}+\beta_{3} \text { RSindex }_{k, t} \times
$$

Dependence $_{i, t}+\gamma Z_{i, k, t}+$ Industry $_{j}+$ Year $_{t}+$ State $_{k}+\varepsilon_{i, t}$

where $i$ indexes company, $t$ indexes time, $j$ indexes industry, and $k$ indexes state. The dependent variable captures company innovation outcomes and is either patent counts or patent citations. We add the new variable, Dependence, ${ }_{t}$ and the interaction term between RSindex and

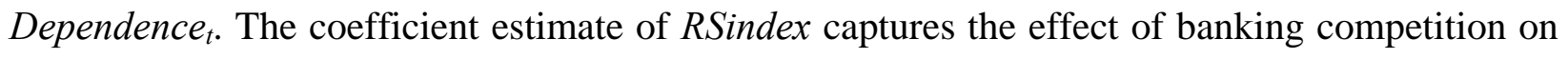
innovation for companies that are more external-finance-dependent. The coefficient on the interaction term reflects the different effects of banking competition on innovation for companies that are less external-finance-dependent. If our conjecture is correct, i.e., if more externalfinance-dependent companies take advantage of banking competition and improve their innovation output, then we expect $\beta_{1}$ to be negative and significant.

[Insert Table 5 here.]

We report the results estimating Eq. (3) in Table 5. In columns (1) and (2), we present the regressions for private firms. The coefficient estimates of RSindex are negative in both specifications and significant at the $1 \%$ or $5 \%$ level, which suggests that banking competition has a positive effect on innovation output by private firms that are more dependent on external finance. Based on the coefficient estimate reported in column (1), more external-financedependent firms located in states that are completely open to interstate branching generate a total of $7.6 \%(=4 \times 0.019)$ more patents in the first three years post branching deregulation than firms in states with the most restrictions on interstate branching. These findings suggest that banking competition enhances innovation by more external-finance-dependent private firms.

Columns (3) and (4) present the results for public corporations. The coefficient estimates of RSindex are negative but insignificant, suggesting that an increase in banking competition (i.e., a decrease in RSindex) does not appear to affect innovation output for corporations that are more dependent on external finance. Based on the coefficient estimate of the interaction term 
reported in column (3), the marginal effect of RSindex for corporations that are less externalfinance-dependent is $0.136 .{ }^{8}$ The evidence suggests that although deregulation adversely affects public corporations' innovation on average, this effect mainly comes from the group of corporations that are less external-finance-dependent. For external-finance-dependent corporations, deregulation does not adversely affect their innovation output.

We examine the robustness of this finding by splitting our sample according to a variety of alternative partition variables that are proxies for external finance dependence, following Acharya, Imbs, and Sturgess (2011) and Hadlock and Pierce (2010). Specifically, we partition our sample based on company size, age, bank-dependence, and the SA index. We follow the same procedure described above for the EFD measure to impute these alternative partition variables from public corporations in industry $j$ in year $t$ to private firms in the same industry and year. We also define Dependence ${ }_{t}$ for these alternative partition variables the same way as before, i.e., it equals one for the firm-years (corporation-years) that are considered to be less external-finance-dependent and zero for firm-years (corporation-years) that are considered to be more external-finance-dependent. For brevity, we focus our attention on private firms in this robustness analysis and report the results in Table 6. Untabulated results from public corporations are qualitatively similar to those reported in Table 5.

[Insert Table 6 here.]

Panel A presents the results when we use assets as the partition variable. Panel B reports the findings if we use age to slice the sample. Panel $C$ presents the results based on bank dependence. We define a sector as bank-dependent if the cumulative dollar value of loans borrowed by companies in the sector up to a given year is greater than the median in the year. Finally, in Panel D, we report the results when the sample is partitioned by the SA index. We observe the coefficient estimates of RSindex are all negative and significant except for columns (4) and (8), suggesting that banking competition has a positive effect on both patent quantity and quality by private firms that are more dependent on external finance. The evidence is consistent with the findings reported in Table 5.

Overall, the evidence reported in this section indicates that banking competition relaxes financial constraints for private firms that are more dependent on external finance. As a

\footnotetext{
${ }^{8}$ Because the coefficient estimate of $R$ Sindex is not statistically significant, the coefficient estimate of the interaction term captures the marginal effect of RSindex for corporations that are less external-finance-dependent.
} 
consequence, these firms generate more patents and their patents receive more citations after deregulation. Therefore, dependence on external finance appears to be one underlying mechanism through which banking competition affects innovation.

\subsection{Prior banking relationships}

Next, we examine whether companies’ prior banking relationships interact with changes in banking competition to affect their innovation output. We hypothesize that in-state banking relationships prior to deregulatory events are evidence that companies are able to satisfy their demand for capital from nearby banks. However, if companies borrow from out-of-state banks prior to deregulatory events, it indicates that such companies are unable to satisfy their demand for capital from nearby banks. Therefore, if banking competition due to interstate branching deregulation expands access to finance and if companies use it to finance their innovative projects, then the innovation output of companies that borrow more from out-of-state banks prior to deregulation should increase following increases in banking competition.

To make the distinction between in-state and out-of-state banking relationships, we collect information from DealScan about the physical locations of banks from which companies take loans. DealScan reports the state in which a lender is located. In the case that multiple lenders are reported for a particular loan (facility), we select the lead arranger as the representative lender for a particular loan. In the case that multiple lenders are identified as the lead arranger, we use the lead arranger with the largest percentage share in the loan. ${ }^{9}$ Using the data on bank location, we then calculate the cumulative dollar amount of loans a company has borrowed up to year $t$ from in-state and out-of-state banks, separately. We set cumulative loans to zero if the company does not have any bank loans prior to the deregulatory event. We then construct an indicator variable, BankLoans, which equals one if the cumulative dollar value of loans borrowed by a company up to a given year is smaller than the median in that year and zero otherwise. We then estimate the following model:

$$
\begin{aligned}
& \text { LnPat }_{i, t+1} \text { to } t+3 \\
& \left(\text { LnCite }_{i, t+1} \text { to } t+3\right)=\alpha+\beta_{1} \text { RSindex }_{k, t}+\beta_{2} \text { BankLoans }_{i, t}+\beta_{3} \text { RSIndex }_{k, t} \times \\
& \text { BankLoans }_{i, t}+\gamma Z_{i, k, t}+\text { Industry }_{j}+\text { Year }_{t}+\text { State }_{k}+\varepsilon_{i, t}
\end{aligned}
$$

\footnotetext{
${ }^{9}$ In rare cases in which multiple lead arrangers share the largest percentage of the facility, we retain those observations where all the lead arrangers reside in the same state and discard the remaining observations.
} 
where $i$ indexes company, $t$ indexes time, $j$ indexes industry, and $k$ indexes state. The interaction term in Eq. (4) is the key variables of interest in this analysis. If the data support our conjecture, then the coefficient estimate of RSindex, $\beta_{1}$, will be negative and significant for out-of-state banking relationships. Furthermore, compared to public corporations, private firms are more likely to rely on financing from local banks. Therefore, if the data support our conjecture, the distinction between how prior in-state and out-of-state banking relationships interact with banking competition to affect innovation should be more pronounced for private firms than for public corporations.

We report the regression results estimating Eq. (4) in Table 7. In Panel A, we focus on the sample of private firms. None of the coefficient estimates of RSindex is significant in columns (1) and (2), in which in-state bank loans are used as a proxy for prior bank relationships. In contrast, in columns (3) and (4), in which we consider out-of-state loans, we observe negative and significant coefficient estimates of RSindex. In addition, these coefficients are larger in economic magnitude compared to their counterparts in columns (1) and (2). Consistent with our conjecture, this result suggests that in-state banking relationships indicate that a firm is able to successfully raise capital from nearby banks prior to any deregulatory events. These firms are insensitive to changes in the in-state banking environment because they have pre-existing banking relationships. However, firms relying more on out-of-state bank credit before deregulation benefit most from the deregulation because it allows them to access credit from instate banks. These firms appear to take advantage of expanded access to in-state bank finance in the sense that they generate a larger number of patents after deregulation, consistent with our conjecture.

In Panel B, we turn our attention to the sample of public corporations. The coefficient estimates of RSindex are insignificant irrespective of whether in-state bank loans or out-of-state loans are used as a proxy for prior bank relationships. These results suggest that the mechanism of prior banking relationships plays a role only for private firms that are more likely to rely on financing from local banks.

\section{[Insert Table 7 here.]}

Overall, the evidence presented in this section suggests that an increase in access to credit due to banking deregulation positively affects firms' innovation output if they mainly obtain loans from out-of-state banks before the deregulatory event. 


\subsection{Acquisitions of private firms by public corporations}

Our evidence so far shows that state-level banking competition has a positive effect on innovation by external-finance-dependent private firms and a negative effect on innovation by public corporations. In this section, we explore a possible mechanism - the acquisitions of small, innovative firms - that might explain why banking competition negatively affects corporations' innovation output. Sevilir and Tian (2012) show that U.S. publicly traded corporations enhance their innovativeness through acquisitions of small, innovative firms (that are usually privately held) and that acquisitions play at least as important a role as R\&D expenditures in promoting innovation. If interstate branching deregulation expands the availability of credit to small, innovative firms at a lower cost, these firms could be more likely to take advantage of bank lending to finance themselves and remain independent instead of agreeing to an acquisition to ease their financial constraints. ${ }^{10}$ Put differently, banking competition may affect corporations' innovation output as these corporations become less able to acquire innovative target firms after interstate branching deregulation. We test this hypothesis from two perspectives.

We first examine this hypothesis from the demand (acquirer) side by studying whether corporations are less likely to acquire innovative target firms after deregulation. It is natural to believe that, based on the findings in Sevilir and Tian (2012), corporations that make many acquisitions (frequent acquirers) have greater willingness or ability to enhance innovation through acquisitions compared to corporations that make acquisitions less frequently or corporations that never make acquisitions. If banking competition affects corporate innovation output through impaired abilities of corporations to acquire small, innovative target firms, we should expect that the negative effect of banking competition on corporate innovation output is more pronounced for frequent acquirers.

To test this conjecture, we conduct our analyses at the corporation level for a sample of publicly traded corporations. We assign the value of RSindex based on the corporation's headquarter state. We estimate the following model:

$$
\begin{array}{r}
\text { LnPat }_{i, t+1 \text { to } t+3}=\alpha+\beta_{1} \text { RSindex }_{k, t}+\beta_{2} \text { Acquisition }_{i, t}+\beta_{3} \text { RSindex }_{k, t} \times \text { Acquisition }_{i, t}+ \\
\gamma Z_{i, k, t}+\text { Industry }_{j}+\text { Year }_{t}+\text { State }_{k}+\varepsilon_{i, t}
\end{array}
$$

\footnotetext{
${ }^{10}$ Erel, Jang, and Weisbach (2013) find that mergers and acquisitions significantly ease financial constraints of target firms.
} 
where $i$ indexes corporation, $t$ indexes time, $j$ indexes industry, and $k$ indexes state. We de-mean both variables of the interaction term for ease of the interpretation of $\beta_{3}$. To create an acquisition measure, we use the transaction value in SDC that is reported for each deal. In the case that a transaction value is not reported we replace the transaction value with zero. We construct three proxies for a corporation's acquisition volume: Dollar Volume, which is the corporation's total dollar amount spent on mergers and acquisitions (M\&As) divided by corporation assets; Number of Deals, which is the total number of M\&As a corporation undertakes in a year; and Dollar per Deal, which is the total dollar amount of M\&A spending divided by corporation assets and the number of M\&A deals. $Z$ is a vector of corporation and industry characteristics that includes investments in intangible assets ( $\& \mathrm{D} /$ total assets), profitability (ROA), asset tangibility (net PPE/total assets), leverage, capital expenditures (capital expenditures/total assets), industry concentration (Herfindahl index based on sales), growth opportunities (Tobin's $Q$ ), corporation size (the natural logarithm of book value assets), and corporation age. The key variable of interest is $\beta_{3}$, the coefficient estimate of the interaction term. If our conjecture is correct, we expect to observe a positive and significant coefficient estimate of $\beta_{3}$.

Table 8 reports the regression results from estimating Eq. (5). The coefficient estimates of the interaction terms are positive and statistically significant at the 5\% level in columns (1) and (3), suggesting that the negative effects of banking competition on corporation innovation output are more pronounced for corporations that are frequent acquirers. For example, based on the coefficient estimate reported in column (1), the marginal effect of banking competition on corporations innovativeness is $0.008(\mathrm{p}$-value $=0.077)$ if a corporation's acquisition amount is at the sample mean. If a corporation's acquisition amount is above the sample mean by one standard deviation (0.548), then the marginal effect of banking competition on innovation output in the next three years increases by $2.3 \%(0.008+0.040 \times 0.548=0.023) .{ }^{11}$ These results indicate that frequent acquirers experience a decrease in their post-deregulation innovation output, which is consistent with our conjecture.

\section{[Insert Table 8 here.]}

Next, we test whether small, innovative firms’ improved access to credit allows them to stay independent, which indirectly hurts public corporations' innovation output. We construct

\footnotetext{
${ }^{11}$ The standard deviation of dollars used in acquisitions each year is \$36.2 million. However, in Eq. (5), we standardize the independent variable Acquisition $_{i, t}$ by a corporation's total assets in year $t$. The standard deviation of this variable is 0.548 .
} 
two measures that capture the innovativeness of the target firms acquired by corporations in our sample. (We refer to these two measures as TargetInnov in Eq. (6) below.) The first measure is the total number of patents generated during the entire sample period by all target firms acquired in year $t$ (TargetCount). The second measure is the total number of patents generated during the entire sample period by all target firms acquired in year $t$ normalized by the number of target firms acquired in a year (TargetCountPerAcq). ${ }^{12}$ To construct the two measures, we begin by matching patent filings from the NBER database to each target firm in SDC and sum the number of patents each target generates over the course of the sample period. Next we merge the M\&A deal data in SDC to acquiring corporations in Compustat. ${ }^{13}$ For states with multiple regulation changes, we repeat the observations from that state for every regulation change reported in Rice and Strahan (2010). Because both of these measures are highly right skewed, we use a zeroinflated negative binomial model to estimate the following equation:

$$
\text { TargetInnov }_{i, t}=\alpha+\beta \text { RegChg }_{i, t}+\gamma Z_{i, t}+\text { Firm }_{i}+\text { Year }_{t}+\varepsilon_{i, t}
$$

where $i$ indexes corporation and $t$ indexes time. ${ }^{14}$ RegChg is a dummy that equals one if a deregulation occurs in the state in which the corporation is headquartered and zero otherwise. The above specification is essentially the difference-in-differences approach used by Bertrand and Mullianathan (2003). The year fixed effects control for aggregate fluctuations in target innovativeness, and by de-meaning the independent variables we control for any time-invariant differences between treatment corporations (corporations located in states where deregulation occurs) and control corporations (corporations located in states where deregulation does not occur). The key variable of interest is $\operatorname{RegChg}$, and $\beta$ is the differences-in-differences estimator.

We present the regression results in Table 9. We report the marginal effects of independent variables because the coefficients of the negative binomial model are difficult to

\footnotetext{
${ }^{12}$ We round this variable to the nearest integer to facilitate our estimation of Eq. (3) in the zero-inflated negative binomial model. We discuss these results below.

${ }^{13}$ When we begin matching the NBER patent data to the list of SDC acquisition deals, there are 10,955 targetacquirer pairs in SDC. Of these acquisition deals, approximately $21 \%(2,359)$ involve a target firm that generates at least one patent during the sample period. Because an acquiring corporation can transact multiple deals in a single year, we aggregate the deals to the acquiring corporation-year level and merge the data with the corporation data in Compustat. There are 15,700 corporations in the main sample. Nine percent $(1,454)$ of the corporations acquire a target that produces patents. However, because acquiring corporations tend to have a shorter life span than nonacquiring corporations in our sample period, the overall number of corporation-year observations with non-zero patents from acquisitions is very small. In fact, of the 133,792 corporation-year observations only $1.63 \%(2,185)$ have non-zero patents from acquisitions.

${ }^{14}$ We conduct the overdispersion test and vuong test for zero inflation and both are statistically significant at the $1 \%$ level, which suggests that the zero-inflated negative binomial model is best suited for our data compared to the Poission model and the standard negative binomial model.
} 
interpret. The coefficient estimates of RegChg are negative and significant in both columns, suggesting the innovativeness of target firms acquired by corporations is lower after deregulation. The marginal effect at the mean for column (1) of Table 9 is -0.07 . Considering the mean value of the sample in Table 9 is 0.33 patents per corporation-year, the magnitude of RegChg suggests that the targets acquired after deregulation produce $21 \%$ fewer patents over their lifetimes than targets acquired before deregulation.

[Insert Table 9 here.]

Overall, our evidence from the demand (acquirer) side suggests that the decrease in innovation output of public corporations after deregulation is at least partly due to the fact that they are less able to acquire innovative target firms. After deregulation, small and innovative firms have better access to bank financing, and therefore can remain independent instead of being acquired.

Next, we explore this conjecture from the supply (target) side by examining whether small and innovative firms are indeed less likely to be acquired (i.e., more likely to remain independent) after deregulation. Specifically, we examine the change in the proportion of innovative target firms surrounding interstate bank branching deregulation. We define a variable, Innovative Target Ratio (ITR), the number of target firms that produce at least one patent in year $t$ headquartered in a state, scaled by the number of private non-farm businesses in that state-year. (We collect data on the number of private non-farm businesses from the U.S. Census Bureau (http://www.census.gov/).) We plot ITR in event time in Fig. 2. The event year is the year when deregulation occurred in a particular state. This measure captures the innovative intensity of firms that are acquired within a state-year. We calculate annual averages of this measure from five years before to five years after the deregulatory event years. Fig. 2 shows amonotonic drop of ITR after deregulation, which is consistent with our argument that small, innovative firms are more likely to remain independent after deregulation because they gain better access to bank credit. This decrease in supply of innovative targets contributes to the post-deregulation drop of innovativeness of public corporations.

[Insert Fig. 2 here.]

In summary, in this section, we discuss a third possible mechanism through which banking deregulation causes a reduction in innovation by public corporations. Deregulation allows small, innovative firms to access bank financing, which allows them to finance 
themselves and remain independent instead of being acquired. This mechanism helps explain the robust, negative effect of bank deregulation on corporate innovation output documented in our baseline analysis.

\section{Extensions and conclusion}

We extend our work by examining the impact on innovation of the changes in bank entry and failure rates that resulted from the deregulation events we study in this paper. Subramanian and Yadav (2012) show that deregulation of bank entry enhances bank stability by lowering instances of bank failures. It is possible that our primary independent variable, RSindex, merely

proxies for bank entry or failure rates. Therefore, we test whether our results are sensitive to controlling for bank entry and bank failures. In results tabulated in the Internet Appendix, we show that our results are robust to including these controls. We also extend our work by examining whether banking competition affects the way banks lend to external-financedependent companies. Using bank lending data from Dealscan and the proxies for external finance dependence used in Section 5.1, we find suggestive evidence that banking competition leads to more loans and larger loans to external-finance-dependent companies. We report these results in the Internet Appendix, as well.

In conclusion, this paper examines the effect of banking competition on innovation. We exploit the staggered deregulation of state-level branching laws to identify changes in banking competition. We find that these events cause overall reductions in state-level innovation. This result is driven by corporations headquartered within states that deregulate. In contrast, we find that innovation increases among external-finance-dependent private firms. Branching deregulation expands access to credit for these firms, which relaxes their financial constraints and allows them to pursue innovative projects. Consistent with this result, we find evidence that the drop in corporate innovation is at least partly due to a reduction in the supply of innovative target firms. After branching deregulation, private firms are able to secure bank financing to secure innovative projects instead of agreeing to be acquired by corporations. This finding supports the view that banking was repressed in the United States until branching deregulation was enacted. 


\section{References}

Acharya, V., Baghai, R., Subramanian, K., 2011. Labor laws and innovation. Unpublished working paper.

Acharya, V., Baghai, R., Subramanian, K., 2012. Wrongful discharge laws and innovation. Review of Financial Studies, forthcoming.

Acharya, V., Imbs, J., Sturgess, J., 2011. Finance and efficiency: do bank branching regulation matter? Review of Finance 15, 135-172.

Acharya, V., Subramanian, K., 2009. Bankruptcy codes and innovation. Review of Financial Studies 22, 4949-4988.

Aghion, P., Bloom, N., Blundell, R., Griffith, R., Howitt, P., 2005. Competition and innovation: an inverted-U relationship. Quarterly Journal of Economics 120, 701-728.

Aghion, P., Van Reenen, J., Zingales, L., 2013. Innovation and institutional ownership. American Economic Review 103, 227-304.

Amore, M., Schneider, C., Zaldokas, A., 2013. Credit supply and corporate innovation. Journal of Financial Economics, forthcoming.

Benfratello, L., Schiantarelli, F., Sembenelli, A., 2008. Banks and innovation: microeconometric evidence on Italian firms. Journal of Financial Economics 90, 197-217.

Bertrand, M., Mullainathan, S., 2003. Enjoying the quiet life? Corporate governance and managerial preferences. Journal of Political Economy 111, 1043-1075.

Black, S., Strahan, P., 2002. Entrepreneurship and bank credit availability. Journal of Finance 57, 2807-2833.

Bolton, P., Von Thadden, E. L., 1998. Blocks, liquidity, and corporate control. Journal of Finance 53, 1-25.

Butler, A., Cornaggia, J., 2011. Does access to external finance improve productivity? Evidence from a natural experiment. Journal of Financial Economics 99, 184-203.

Cetorelli, N., Strahan, P., 2006. Finance as a barrier to entry: Bank competition and industry structure in U.S.. Journal of Finance 61, 437-461.

Chava., S., Oettl, A., Subramanian, A., Subramanian, K., 2013. Banking deregulation, bargaining power and innovation. Journal of Financial Economics, forthcoming.

Dick, A, Lehnert, A., 2010. Personal bankruptcy and credit market competition. Journal of Finance 65, 655-686.

Duchin, R., Ozbas, O., Sensoy, B., 2010. Costly external finance, corporate investment, and the subprime mortgage credit crisis. Journal of Financial Economics 97, 418-435.

Erel, I., Jang, Y., Weisbach, M., 2013. Do acquisitions relieve target firms’ financial constraints? Journal of Finance, forthcoming.

Fang, V., Tian, X., Tice, S., 2013. Does stock liquidity enhance or impede firm innovation? Journal of Finance, forthcoming.

Griliches, Z., Pakes, A., Hall, B., 1988. The value of patents as indicators of inventive activity. Unpublished working paper. 
Hadlock, C., Pierce, J., 2010. New evidence on measuring financial constraints: moving beyond the KZ index. Review of Financial Studies 23, 1909-1940.

Hall, B., Jaffe, A., Trajtenberg, M., 2001. The NBER patent citation data file: lessons, insights and methodological tools. Unpublished working paper.

Hall, B., Jaffe, A., Trajtenberg, M., 2005. Market value and patent citations. RAND Journal of Economics 36, 16-38.

He, J., Tian, X., 2013. The dark side of analyst coverage: the case of innovation. Journal of Financial Economics 109, 856-878.

Hombert, J., Matray, A., 2013. The real effects of hurting lending relationships: evidence from banking deregulation and innovation. Unpublished working paper.

Hsu, P., Tian, X., Xu, Y., 2013. Financial development and innovation: Cross country evidence. Journal of Financial Economics, forthcoming.

Jayaratne, J., Strahan, P., 1996. The finance-growth nexus: Evidence from bank branch deregulation. Quarterly Journal of Economics 111, 639-670.

Kerr, W., Nanda, R., 2009. Democratizing entry: banking deregulations, financing constraints, and entrepreneurship. Journal of Financial Economics 94, 124-149.

Kroszner, R., Strahan, P., 1999. What drives deregulation? Economics and politics of the relaxation of bank branching restrictions. Quarterly Journal of Economics 114, 1437-1469.

Meulbroek, L., Litchell, M., Mulherin, H., Netter, J., Poulsen, A., 1990. Shark repellents and managerial myopia: an empirical test. Journal of Political Economy 98, 1108-1117.

Morgan, D., Rime, B., Strahan, P., 2004. Bank integration and state business cycles. Quarterly Journal of Economics 119, 1855-1885.

Petersen, M., Rajan, R., 2002. Does distance still matter? The information revolution in small business lending. Journal of Finance 57, 2533-2570.

Porter, M., 1992. Capital disadvantage: America’s failing capital investment system. Harvard Business Review 70, 65-82.

Rice, T., Strahan, P., 2010. Does credit competition affect small-firm finance? Journal of Finance 65, 861-889.

Robinson, J., 1952. The generalization of the general theory, in: the rate of interest and other essays. London, MacMillan.

Schumpeter, 1911. The theory of economic development. Harvard economic studies, Vol. XLVI Cambridge, MA. Harvard University Press.

Seru, A., 2012. Firm boundaries matter: evidence from conglomerates and R\&D activity. Journal of Financial Economics, forthcoming.

Sevilir, M., Tian, X., 2012. Acquiring innovation. Unpublished working paper.

Solow, R., 1957, Technological change and the aggregate production function. Review of Economics and Statistics 39, 312-320.

Subramanian, K., Yadav, A., 2012. Deregulation of bank entry and bank failures. Unpublished working paper.

Tian, X., Wang, T., 2012. Tolerance for failure and corporate innovation. Review of Financial Studies, forthcoming. 


\section{Appendix}

Variable Definitions.

\begin{tabular}{|c|c|}
\hline Variable & Definition \\
\hline \multicolumn{2}{|c|}{ Measures of innovation } \\
\hline $\begin{array}{l}\text { LnPat } \\
\text { (state) }\end{array}$ & $\begin{array}{l}\text { Natural logarithm of one plus state } j \text { 's total number of patents filed } \\
\text { (and eventually granted) in years } t+1 \text { through } t+3 \text {. }\end{array}$ \\
\hline $\begin{array}{l}\text { LnCite } \\
\text { (state) }\end{array}$ & $\begin{array}{l}\text { Natural logarithm of one plus state } j \text { 's total number of citations } \\
\text { received on the firm's patents filed (and eventually granted) in years } \\
t+1 \text { through } t+3 \text {. }\end{array}$ \\
\hline $\begin{array}{l}\text { LnPat } \\
\text { (corporation) }\end{array}$ & $\begin{array}{l}\text { Natural logarithm of one plus corporation } i \text { 's total number of patents } \\
\text { filed (and eventually granted) in years } t+1 \text { through } t+3 \text {. }\end{array}$ \\
\hline $\begin{array}{l}\text { LnCite } \\
\text { (corporation) }\end{array}$ & $\begin{array}{l}\text { Natural logarithm of one plus corporation } i \text { 's total number of citations } \\
\text { received on the firm's patents filed (and eventually granted) in years } \\
t+1 \text { through } t+3 \text {. }\end{array}$ \\
\hline $\begin{array}{l}\text { LnPat } \\
\text { (firm) }\end{array}$ & $\begin{array}{l}\text { Natural logarithm of one plus firm } i \text { 's total number of patents filed } \\
\text { (and eventually granted) in years } t+1 \text { through } t+3 \text {. }\end{array}$ \\
\hline $\begin{array}{l}\text { LnCite } \\
\text { (firm) }\end{array}$ & $\begin{array}{l}\text { Natural logarithm of one plus firm } i \text { 's total number of citations } \\
\text { received on the firm's patents filed (and eventually granted) in years } \\
t+1 \text { through } t+3 \text {. }\end{array}$ \\
\hline $\begin{array}{l}\text { Generality } \\
\text { (state) }\end{array}$ & $\begin{array}{l}\text { One minus the Herfindahl index of the three-digit technology class } \\
\text { distribution of all the patents that cite a given patent. We then take the } \\
\text { average for all patents generated by the state. }\end{array}$ \\
\hline $\begin{array}{l}\text { Originality } \\
\text { (state) }\end{array}$ & $\begin{array}{l}\text { One minus the Herfindahl index of the three-digit technology class } \\
\text { distribution of all the patens that a given patent cites. We then take the } \\
\text { average for all patents generated by the state. }\end{array}$ \\
\hline TargetCount & $\begin{array}{l}\text { TargetCount is a measure of the patents corporation } i \text { receives from } \\
\text { acquiring targets and is calculated in two steps. First we calculate the } \\
\text { sum of all patents generated by a target during the 1976-2006 sample. } \\
\text { Then we sum the number of patents generated by all the targets of } \\
\text { corporation } i \text { in year } t \text {, which is the year that the targets are acquired. }\end{array}$ \\
\hline TargetCountPerAcq & $\begin{array}{l}\text { TargetCountPerAcq is a measure of the patents corporation } i \text { receives } \\
\text { per target and is calculated in three steps. First we calculate the sum of } \\
\text { all patents generated by a target during the 1976-2006 sample. Then } \\
\text { we sum the number of patents generated by all the targets of } \\
\text { corporation } i \text { in year } t \text {, which is the year that the targets are acquired. } \\
\text { Finally, we divide by the number of targets acquired by corporation } i \\
\text { in vear } t \text {. }\end{array}$ \\
\hline
\end{tabular}

Measure of deregulation and control variables used in baseline specifications

RSindext

Rice-Strahan index of interstate banking deregulation based on Rice and Strahan (2010). It ranges from 0 (deregulated) to 4 (highly regulated) based on regulation changes in a state.

Intra

An indicator variable that takes the value of 0 prior to intra-state deregulation during the 1970s, 1980s, and 1990s as described in Jayaratne and Strahan (1996). The indicator takes the value of one from the year of intrastate deregulation onward. 
Inter

An indicator variable that takes the value of 0 prior to inter-state deregulation during the 1980s and 1990s as described in Black and Strahan (2002). The indicator takes the value of one from the year of intrastate deregulation onward.

Assets $_{t} \quad$ Natural logarithm of the book value of total assets (at) measured at the end of fiscal year $t$.

Before $^{l} \quad$ A variable that takes the value of $1 \times\left(\Delta R \operatorname{Sindex}_{t}\right)$ the year prior to a
regulatory change and 0 otherwise. $\Delta R \operatorname{Rindex_{t}}$ is the magnitude of the change in $R$ Sindex $_{t}$ during a deregulatory event.

Before $^{2+} \quad$ A variable that takes the value of $1 \times\left(\Delta R\right.$ Sindex $\left._{t}\right)$ from the beginning of the window up to two years prior to a regulatory change and 0 otherwise. $\Delta$ RSindex $_{t}$ is the magnitude of the change in RSindex during a deregulatory event.

After $^{2+} \quad$ A variable that takes the value of $1 \times\left(\Delta R\right.$ Sindex $\left._{t}\right)$ in the second year following a deregulation until the end of the window and 0 otherwise. $\Delta R$ Sindex $_{t}$ is the magnitude of the change in RSindex during a deregulatory event.

After $^{l} \quad$ A variable that takes the value of $1 \times\left(\Delta R\right.$ Sindex $\left._{t}\right)$ in the year following a regulatory change and 0 otherwise. $\Delta R$ Sindex $_{t}$ is the magnitude of the change in $R$ Sindex $_{t}$ during a deregulatory event.

R\&DAssets $\quad$ Research and development expenditure (xrd) divided by book value of total assets (at) measured at the end of fiscal year $t$, set to 0 if missing.

Age $_{t} \quad$ Company $i$ 's age. It equals the number of years the corporation has existed since the founding year obtained from Jay Ritter's dataset.

$R_{R} \quad$ Return-on-assets ratio defined as operating income before depreciation (oibdp) divided by book value of total assets (at), measured at the end of fiscal year $t$.

PPEAssets $_{t} \quad$ Property, Plant \& Equip (net, ppent) divided by book value of total assets (at) measured at the end of fiscal year $t$.

Leverage $_{t} \quad$ Corporation $i$ 's leverage ratio, defined as book value of debt (dltt+dlc) divided by book value of total assets (at) measured at the end of fiscal year $t$.

CapexAssets $_{t} \quad$ Capital expenditure (capx) scaled by book value of total assets (at) measured at the end of fiscal year $t$.

Tobin $Q_{t} \quad$ Corporation $i$ 's market-to-book ratio during fiscal year $t$, calculated as [market value of equity (prcc_f $\times$ csho) plus book value of assets (at) minus book value of equity (ceq) minus balance sheet deferred taxes (txdb, set to 0 if missing)] divided by book value of assets (at).

Hindex $_{t} \quad$ Herfindahl index of 4-digit SIC industry $j$ of corporation $i$, measured at the end of fiscal year $t$ based on sales.

Measure of other variables

Dollar Volume $\quad$ The dollar volume in millions of private acquisition deals from SDC data for corporation $i$ in year $t$.

Number of Deals $s_{t} \quad$ The natural log of one plus the number of private acquisition deals 


\begin{tabular}{|c|c|}
\hline & from SDC data for corporation $i$ in year $t$. \\
\hline$\overline{\text { Dollars per Deal }}$ & $\begin{array}{l}\text { The dollar volume of private acquisition deals from SDC data for } \\
\text { corporation } i \text { in year } t \text {, scaled by its total assets (at) at time } t \text { divided by } \\
\text { the number of private acquisition deals of corporation } i \text { in year } t \text {. }\end{array}$ \\
\hline $\begin{array}{l}\text { Mining (Construction, } \\
\text { Manufacturing, } \\
\text { Transportation, Trade, } \\
\text { Finance, Services, } \\
\text { Government) }\end{array}$ & $\begin{array}{l}\text { The labor share of state } i \text { in year } t \text { in mining (construction, } \\
\text { manufacturing, transportation, trade, finance, services, government). } \\
\text { The labor share is defined as the fraction of gross product in state } i \text { in } \\
\text { year } t \text { that is from mining (construction, manufacturing, transportation, } \\
\text { trade, finance, services, government) industries. Industry is defined by } \\
\text { NAICS category from 1998-2006, and SIC code from 1976-1997. }\end{array}$ \\
\hline Concentration & $\begin{array}{l}\text { The labor force concentration of state } i \text { in year } t \text {. The labor force } \\
\text { concentration is defined as the sum of the squared labor shares for } \\
\text { state } i \text { in year } t \text {. }\end{array}$ \\
\hline Gross Product & The nominal gross product in state $i$ in year $t$. \\
\hline Dependence $_{t}$ & $\begin{array}{l}\text { A dummy variable indicating low (high) External Finance Dependence } \\
\text { (EFD) of company } i \text { measured at the end of fiscal year } t \text {. In the case of } \\
\text { a patenting firm-year, we draw the EFD calculation from the firm's } \\
\text { patent portfolio. For non-patenting firm-years, we carry forward the } \\
\text { EFD from the previous year for private firms or directly calculate it } \\
\text { from Compustat data for public firms. To calculate a patenting firm- } \\
\text { year level EFD, we classify each patent by its 4-digit IPC and link it to } \\
\text { a distribution of 3-digit SIC codes. Each of these } 3 \text { digit SIC codes } \\
\text { then matches to an EFD calculated from public corporations in that } \\
\text { year. External Finance Dependence for each } 3 \text { digit SIC is calculated } \\
\text { by first calculating each firm's EFD in year } t \text { within a specific 3-digit } \\
\text { SIC as [Capital Expenditures (capx) - Funds From Operations } \\
\text { (fopt)]/(Capital Expenditures (capx)). When fopt is missing, Funds } \\
\text { From Operations is defined as fopt = [Income Before Extraordinary } \\
\text { Items (ibc) plus Depreciation and Amortization (dpc) plus Deferred } \\
\text { Taxes (txdc) plus (Equity in Net Loss)/Earnings (esubc) plus Sale of } \\
\text { Property, Plant, and Equipment and Investments gain/loss (sppiv) plus } \\
\text { Funds from Operations Other (fopo)]. The industry level, 3-digit SIC, } \\
\text { is annually taken as the median firm EFD for each 3-digit SIC. }\end{array}$ \\
\hline $\begin{array}{l}\text { BankLoans }_{t} \\
\text { (In-State) }\end{array}$ & $\begin{array}{l}\text { The cumulative dollar value ( } \$ \text { millions) of loans (facilities) as } \\
\text { reported in DealScan for company } i \text { in year } t \text { granted by lenders from } \\
\text { the same state as company } i \text { 's headquarter state. The cumulative dollar } \\
\text { value is scaled by the total assets of company } i \text { in year } t \text {. For } \\
\text { companies with zero cumulative loans in the first year of the } \\
\text { headquarters' state deregulation, all subsequent years are set to zero. }\end{array}$ \\
\hline $\begin{array}{l}\text { BankLoans }_{t} \\
\text { (Out-of-State) }\end{array}$ & $\begin{array}{l}\text { The cumulative dollar value ( } \$ \text { millions) of loans (facilities) as } \\
\text { reported in DealScan for company } i \text { in year } t \text { granted by lenders not } \\
\text { located in the same state as company } i \text { 's headquarter state. The } \\
\text { cumulative dollar value is scaled by the total assets of company } i \text { in } \\
\text { year } t \text {. For companies with zero cumulative loans in the first year of } \\
\text { the headquarters' state deregulation, all subsequent years are set to } \\
\text { zero. }\end{array}$ \\
\hline
\end{tabular}



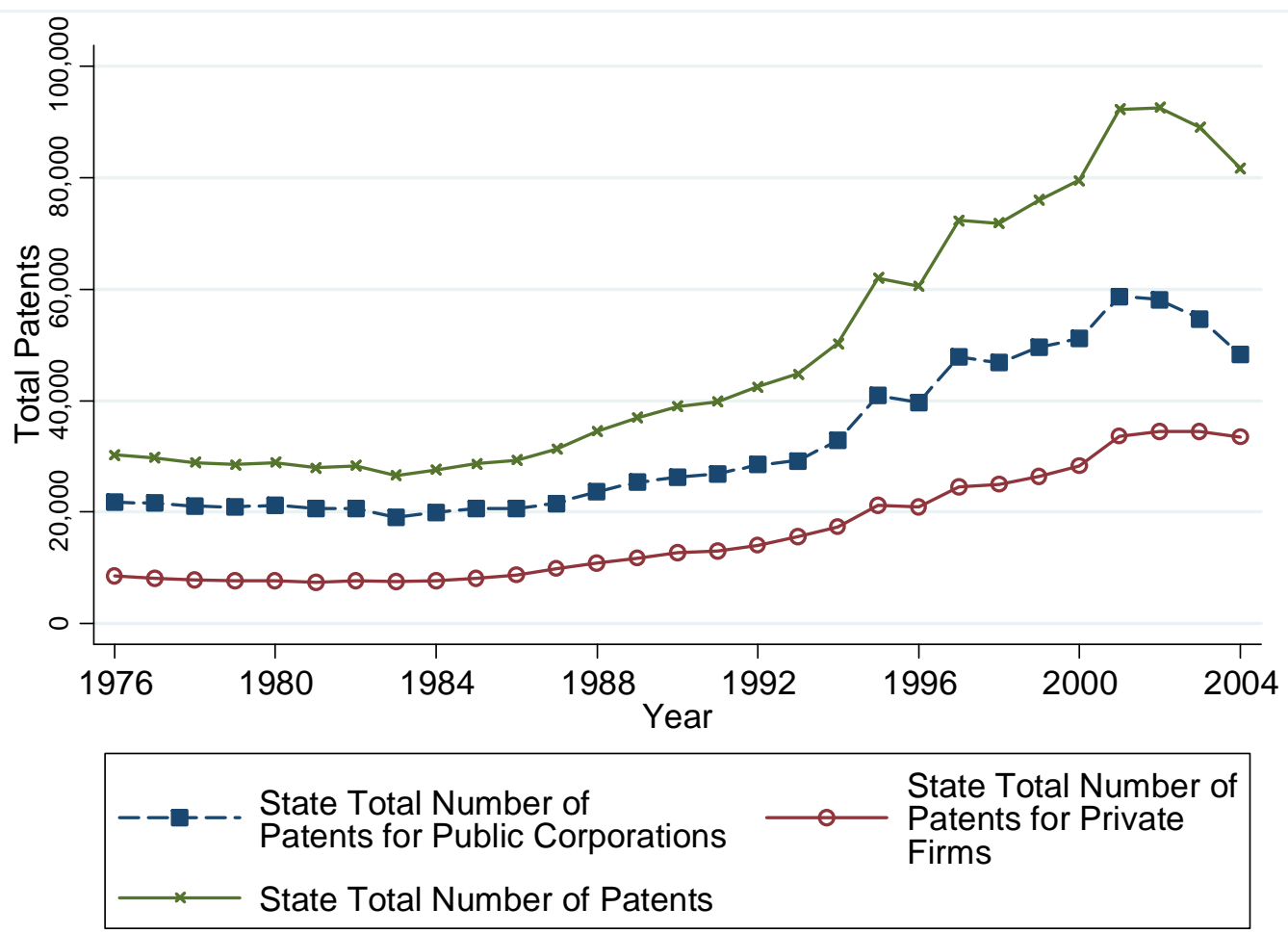

Fig. 1. Patent production through time for corporations and private firms. This figure shows, for each year from 1976-2004, the total number of patents produced by U.S. corporations, the total number of patents produced by private firms in the U.S., and the sum of the two. We identify a patent as being produced by a corporation if it matches to a Compustat firm. We assume a private firm produces the patent if it does not match to a Compustat firm. We remove from the sample patents produced by universities, governments, and foreign companies. 


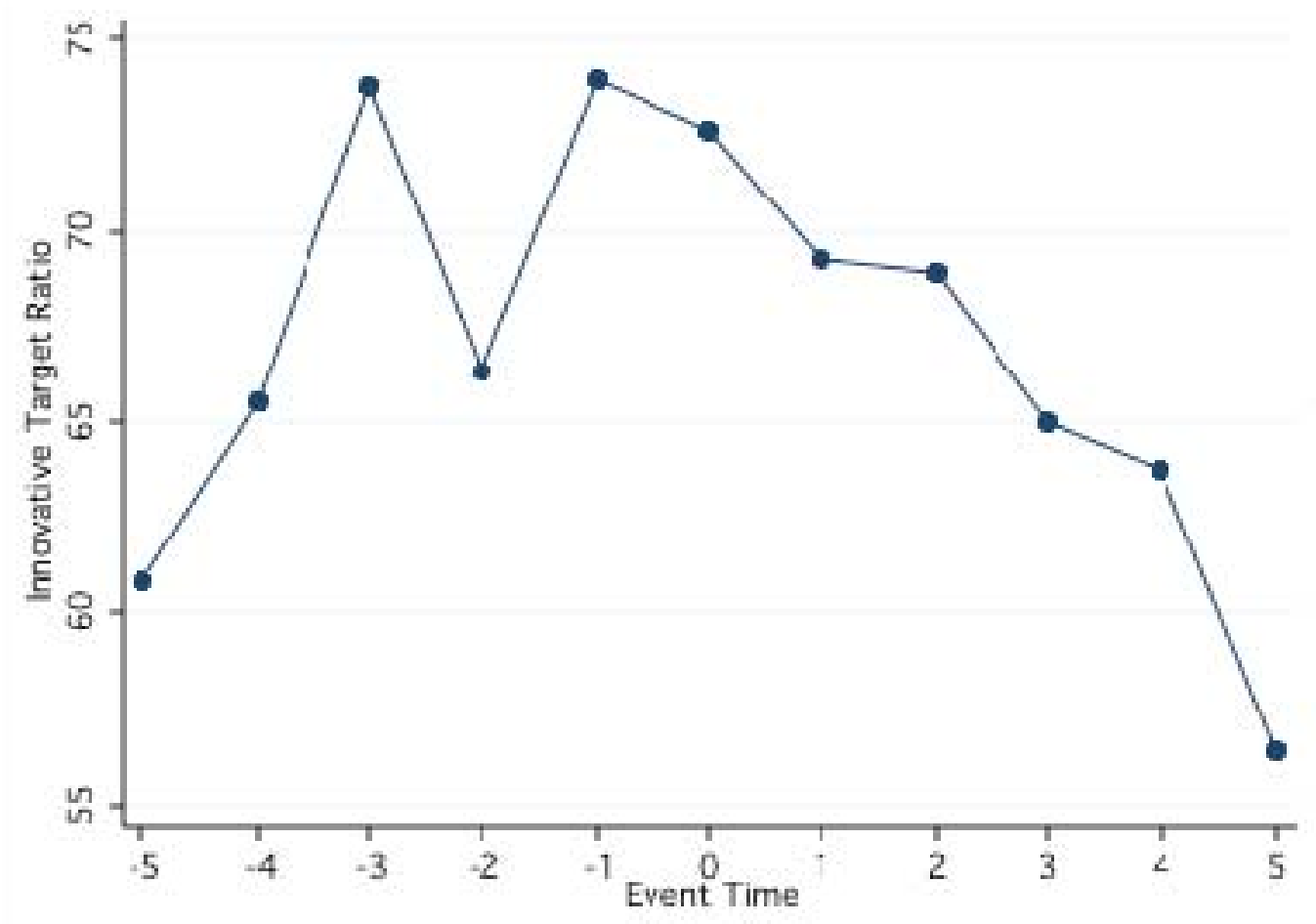

Fig 2. Innovative Target Ratio of acquisition targets across state regulation changes. This figure plots states' average Innovative Target Ratios (ITR) from five years before to five years after a regulation change. We calculate $I T R_{t}$ by dividing the number of targets headquartered within a state with at least one patent filing in year $t$ by the total number of private firms in that state-year. We transform the state-year observations to event time, with a regulation change in a particular state being an event. The observations for states with multiple regulation changes appear in the sample for each event. 


\section{Table 1}

Summary statistics

This table reports summary statistics for the state-year, public corporation-year, and private firm-year observations in this paper's sample, including dependent, independent, and control variables. Corporation and patent data come from Compustat and the NBER patent database from 1976-2006. We obtain data from DealScan to construct banking relationships measures from 1987-2006 and data from SDC to construct acquisition measuresfrom 1976-2006. Definitions of the variables are in the Appendix.

Panel A: State-year observations

\begin{tabular}{lcccccc}
\hline Variable & $\mathrm{p} 25$ & Median & Mean & p75 & S.D. & $\mathrm{N}$ \\
\hline RSindex & 4 & 4 & 3.5 & 4 & 1.11 & 1,426 \\
Pat (state) & 157 & 798 & 2,988 & 3,166 & 6,199 & 1,426 \\
Pat (corporation) & 32 & 305 & 1,962 & 1,643 & 4,483 & 1,426 \\
Pat (firm) & 106 & 388 & 1,026 & 1,209 & 1,852 & 1,426 \\
Cite (state) & 1,379 & 7,521 & 39,085 & 36,277 & 95,369 & 1,426 \\
Cite (corporation) & 250 & 2,531 & 26,778 & 18,767 & 69,552 & 1,426 \\
Cite (firm) & 913 & 3,848 & 12,307 & 13,623 & 27,510 & 1,426 \\
Mining (\%) & 0.16 & 0.56 & 3.42 & 2.56 & 7.16 & 1,426 \\
Construction (\%) & 3.90 & 4.44 & 4.62 & 5.13 & 1.40 & 1,426 \\
Manufacturing (\%) & 12.0 & 17.2 & 17.2 & 23.1 & 8.0 & 1,426 \\
Transportation (\%) & 2.75 & 3.43 & 3.64 & 4.11 & 1.83 & 1,426 \\
Trade (\%) & 13.8 & 15.3 & 14.8 & 16.4 & 2.6 & 1,426 \\
Finance (\%) & 4.28 & 5.11 & 5.96 & 6.38 & 3.41 & 1,426 \\
Services (\%) & 13.4 & 16.6 & 17.6 & 21.1 & 5.8 & 1,426 \\
Government (\%) & 11.2 & 13.3 & 14.3 & 15.8 & 5.0 & 1,426 \\
Concentration (\%) & 11.5 & 12.5 & 13.1 & 13.8 & 2.9 & 1,426 \\
Gross Product (billion) & 25.4 & 58.0 & 113.9 & 136.8 & 158.4 & 1,426 \\
\hline
\end{tabular}


Panel B: Public corporation-year observations

\begin{tabular}{lcccccc}
\hline Variable & $\mathrm{p} 25$ & Median & Mean & $\mathrm{p} 75$ & $\mathrm{~S} . \mathrm{D}$. & $\mathrm{N}$ \\
\hline Pat & 0 & 0 & 4.97 & 2 & 15.38 & 114,937 \\
Cite & 0 & 0 & 57.76 & 22.53 & 178.73 & 114,937 \\
EFD & -0.63 & -0.38 & -0.27 & -0.11 & 0.78 & 114,728 \\
In State Loan(millions) & 0 & 0 & 7 & 0 & 150 & 79,101 \\
Out of State (millions) & 0 & 0 & 33 & 0 & 288 & 79,101 \\
Assets (millions) & 20 & 99 & 1,018 & 625 & 2,157 & 84,902 \\
Age & 8 & 17 & 20.10 & 31 & 14.30 & 88,986 \\
SA index & -15.27 & -9.36 & -10.58 & -5.49 & 6.08 & 84,902 \\
R\&DAssets & 0 & 0 & 0.04 & 0.03 & 0.10 & 133,643 \\
ROA & 0.02 & 0.11 & 0.02 & 0.17 & 0.40 & 133,643 \\
PPEAssets & 0.12 & 0.26 & 0.32 & 0.48 & 0.25 & 133,643 \\
Leverage & 0.11 & 0.26 & 0.31 & 0.41 & 0.3 & 133,643 \\
CapexAssets & 0.02 & 0.05 & 0.07 & 0.09 & 0.08 & 133,643 \\
Hindex & 0.11 & 0.18 & 0.23 & 0.30 & 0.18 & 133,643 \\
TobinQ & 0.99 & 1.3 & 2.1 & 2.0 & 3 & 133,643 \\
Dollar Volume (millions) & 0 & 0 & 4.1 & 0 & 36.2 & 119,843 \\
Number of Deals & 0 & 0 & 0.21 & 0 & 0.84 & 119,843 \\
Dollars Per Deal & 0 & 0 & 0.02 & 0 & 0.41 & 119,843 \\
\hline
\end{tabular}

Panel C: Private firm-year observations

\begin{tabular}{lcccccc}
\hline Variable & p25 & Median & Mean & p75 & S.D. & N \\
\hline Pat & 0 & 0 & 0.73 & 1 & 0.92 & 463,831 \\
Cite & 0 & 0 & 7.02 & 9.25 & 12.03 & 463,831 \\
EFD & -0.73 & -0.47 & -0.31 & -0.19 & 0.91 & 462,672 \\
In State Loan(millions) & 0 & 0 & 0.04 & 0 & 3.38 & 342,524 \\
Out of State (millions) & 0 & 0 & 0.36 & 0 & 24.01 & 342,524 \\
TargetCount & 0 & 0 & 0.33 & 0 & 21.1 & 119,843 \\
TargetCountPerAcq & 0 & 0 & 0.21 & 0 & 11.7 & 119,843 \\
\hline
\end{tabular}




\section{Table 2}

Baseline regressions

This table reports OLS regression estimates for baseline regressions. Panel A reports the OLS regression estimates of Eqs. (1a) and (1b). The dependent variable in columns (1) - (3) is the natural logarithm of one plus the sum of the patents generated in a state in the next three years. The dependent variable in column (4) - (6) is the natural logarithm of one plus the number of citations for patents generated in a state in the next three years. Panel B reports the OLS regression estimates of Eqs. (1a) and (1b). The dependent variable in columns (1) - (3) is the patent generality score for patents generated in the next three years. The dependent variable in column (4) - (6) is the patent originality score generated in the next three years. Definitions of control variables are in the Appendix. Robust standard errors clustered by year are reported in parentheses. Significance at the $1 \%, 5 \%$, and $10 \%$ level is indicated by $* * *$, **, and *, respectively. 
Panel A: Patents and patent citations

\begin{tabular}{|c|c|c|c|c|c|c|}
\hline & \multicolumn{3}{|c|}{ LnPat } & \multicolumn{3}{|c|}{ LnCite } \\
\hline & $\begin{array}{l}\text { Total } \\
\text { (1) }\end{array}$ & $\begin{array}{l}\text { Public } \\
\text { (2) }\end{array}$ & $\begin{array}{l}\text { Private } \\
\text { (3) }\end{array}$ & $\begin{array}{c}\text { Total } \\
\text { (4) }\end{array}$ & $\begin{array}{l}\text { Public } \\
\text { (5) }\end{array}$ & $\begin{array}{l}\text { Private } \\
\text { (6) }\end{array}$ \\
\hline RSindex & $\begin{array}{c}0.077 * * * \\
(0.016)\end{array}$ & $0.102 * * *$ & $\begin{array}{c}0.030 \\
(0.018)\end{array}$ & $0.058^{* * *}$ & $0.066^{* *}$ & 0.041 \\
\hline Mining & $\begin{array}{c}0.013 \\
(0.008)\end{array}$ & $\begin{array}{c}0.031^{* *} \\
(0.015)\end{array}$ & $\begin{array}{c}0.001 \\
(0.006)\end{array}$ & $\begin{array}{c}0.013 \\
(0.013)\end{array}$ & $\begin{array}{c}0.098^{* * * *} \\
(0.028)\end{array}$ & $\begin{array}{c}0.000 \\
(0.010)\end{array}$ \\
\hline Construction & $\begin{array}{l}-0.012 \\
(0.008)\end{array}$ & $\begin{array}{l}0.055^{*} \\
(0.029)\end{array}$ & $\begin{array}{c}-0.028^{* *} \\
(0.010)\end{array}$ & $\begin{array}{l}-0.004 \\
(0.010)\end{array}$ & $\begin{array}{c}0.115^{* *} \\
(0.050)\end{array}$ & $\begin{array}{l}-0.023 \\
(0.014)\end{array}$ \\
\hline Manufacturing & $\begin{array}{c}0.016 \\
(0.010)\end{array}$ & $\begin{array}{c}0.023 \\
(0.020)\end{array}$ & $\begin{array}{l}-0.001 \\
(0.007)\end{array}$ & $\begin{array}{c}0.014 \\
(0.014)\end{array}$ & $\begin{array}{c}0.077 * * * \\
(0.023)\end{array}$ & $\begin{array}{l}-0.000 \\
(0.011)\end{array}$ \\
\hline Transportation & $\begin{array}{c}-0.063 * * \\
(0.029)\end{array}$ & $\begin{array}{c}-0.139^{*} \\
(0.077)\end{array}$ & $\begin{array}{c}-0.034^{*} \\
(0.019)\end{array}$ & $\begin{array}{c}-0.082^{* *} \\
(0.031)\end{array}$ & $\begin{array}{l}-0.190 \\
(0.113)\end{array}$ & $\begin{array}{l}-0.042^{*} \\
(0.022)\end{array}$ \\
\hline Trade & $\begin{array}{c}0.122^{* * *} \\
(0.015)\end{array}$ & $\begin{array}{c}0.116^{* * *} \\
(0.035)\end{array}$ & $\begin{array}{c}0.090 * * * \\
(0.014)\end{array}$ & $\begin{array}{c}0.125 * * * \\
(0.024)\end{array}$ & $\begin{array}{c}0.172^{* * *} \\
(0.058)\end{array}$ & $\begin{array}{c}0.077 * * * \\
(0.022)\end{array}$ \\
\hline Finance & $\begin{array}{l}-0.005 \\
(0.009)\end{array}$ & $\begin{array}{l}-0.027 \\
(0.016)\end{array}$ & $\begin{array}{c}0.048 * * * \\
(0.007)\end{array}$ & $\begin{array}{l}-0.017 \\
(0.011)\end{array}$ & $\begin{array}{l}-0.010 \\
(0.022)\end{array}$ & $\begin{array}{c}0.037^{* * *} * \\
(0.009)\end{array}$ \\
\hline Service & $\begin{array}{c}-0.090 * * * \\
(0.010)\end{array}$ & $\begin{array}{c}-0.103^{* * * *} \\
(0.023)\end{array}$ & $\begin{array}{c}-0.083^{* * * *} \\
(0.008)\end{array}$ & $\begin{array}{c}-0.104 * * * \\
(0.016)\end{array}$ & $\begin{array}{c}-0.060 * * \\
(0.025)\end{array}$ & $\begin{array}{c}-0.106 * * * \\
(0.014)\end{array}$ \\
\hline Government & $\begin{array}{c}-0.045^{* * * *} \\
(0.010)\end{array}$ & $\begin{array}{c}-0.069 * * * \\
(0.022)\end{array}$ & $\begin{array}{c}-0.058^{* * * *} \\
(0.010)\end{array}$ & $\begin{array}{c}-0.045^{* *} \\
(0.017)\end{array}$ & $\begin{array}{l}-0.039 \\
(0.037)\end{array}$ & $\begin{array}{c}-0.058^{* * * *} \\
(0.018)\end{array}$ \\
\hline Concentration & $\begin{array}{c}0.002 \\
(0.017)\end{array}$ & $\begin{array}{c}0.075^{* * *} \\
(0.020)\end{array}$ & $\begin{array}{l}-0.028^{*} \\
(0.015)\end{array}$ & $\begin{array}{c}0.009 \\
(0.020)\end{array}$ & $\begin{array}{c}0.060^{* *} \\
(0.026)\end{array}$ & $\begin{array}{c}-0.043^{* *} \\
(0.019)\end{array}$ \\
\hline Gross Product & $\begin{array}{l}-0.000 \\
(0.000)\end{array}$ & $\begin{array}{l}-0.000 \\
(0.000)\end{array}$ & $\begin{array}{c}0.000 \\
(0.000)\end{array}$ & $\begin{array}{c}0.000 \\
(0.000)\end{array}$ & $\begin{array}{l}-0.000 \\
(0.000)\end{array}$ & $\begin{array}{c}0.000 \\
(0.000)\end{array}$ \\
\hline Intra & $\begin{array}{c}-0.226^{* * * *} \\
(0.040)\end{array}$ & $\begin{array}{c}-0.402 * * * \\
(0.060)\end{array}$ & $\begin{array}{c}-0.058 * * * \\
(0.020)\end{array}$ & $\begin{array}{c}-0.253^{* * *} \\
(0.038)\end{array}$ & $\begin{array}{c}-0.468 * * * \\
(0.067)\end{array}$ & $\begin{array}{c}-0.098^{* *} \\
(0.039)\end{array}$ \\
\hline Inter & $\begin{array}{c}-0.095^{* *} \\
(0.035)\end{array}$ & $\begin{array}{l}-0.084 \\
(0.055)\end{array}$ & $\begin{array}{l}-0.045 \\
(0.038)\end{array}$ & $\begin{array}{c}-0.166^{* * *} \\
(0.044)\end{array}$ & $\begin{array}{c}-0.216^{* * *} \\
(0.087)\end{array}$ & $\begin{array}{l}-0.091^{*} \\
(0.046)\end{array}$ \\
\hline Constant & $\begin{array}{c}2.548^{* * * *} \\
(0.455)\end{array}$ & $\begin{array}{l}-0.003 \\
(1.232)\end{array}$ & $\begin{array}{c}3.512 * * * \\
(0.471)\end{array}$ & $\begin{array}{c}4.764 * * * \\
(0.683)\end{array}$ & $\begin{array}{l}-1.876 \\
(1.572)\end{array}$ & $\begin{array}{c}6.068^{* * *} \\
(0.682)\end{array}$ \\
\hline State FE & Yes & Yes & Yes & Yes & Yes & Yes \\
\hline Year FE & Yes & Yes & Yes & Yes & Yes & Yes \\
\hline Observations & 1,426 & 1,426 & 1,426 & 1,426 & 1,426 & 1,426 \\
\hline Adjusted $\mathrm{R}^{2}$ & 0.966 & 0.927 & 0.971 & 0.954 & 0.901 & 0.954 \\
\hline
\end{tabular}


Panel B: Generality and originality

\begin{tabular}{|c|c|c|c|c|c|c|}
\hline & \multicolumn{3}{|c|}{ Generality } & \multicolumn{3}{|c|}{ Originality } \\
\hline & $\begin{array}{l}\text { Total } \\
\text { (1) }\end{array}$ & $\begin{array}{l}\text { Public } \\
\text { (2) }\end{array}$ & $\begin{array}{l}\text { Private } \\
\text { (3) }\end{array}$ & $\begin{array}{l}\text { Total } \\
\text { (4) }\end{array}$ & $\begin{array}{l}\text { Public } \\
\text { (5) }\end{array}$ & $\begin{array}{l}\text { Private } \\
\text { (6) }\end{array}$ \\
\hline RSindex & $\begin{array}{l}-0.002 \\
(0.002)\end{array}$ & $\begin{array}{l}-0.005 \\
(0.005)\end{array}$ & $\begin{array}{l}-0.002 \\
(0.003)\end{array}$ & $\begin{array}{c}-0.002 \\
(0.003)\end{array}$ & $\begin{array}{l}-0.003 \\
(0.005)\end{array}$ & $\begin{array}{l}-0.002 \\
(0.003)\end{array}$ \\
\hline Mining & $\begin{array}{l}-0.001 \\
(0.002)\end{array}$ & $\begin{array}{c}0.001 \\
(0.003)\end{array}$ & $\begin{array}{l}-0.001 \\
(0.002)\end{array}$ & $\begin{array}{l}-0.000 \\
(0.002)\end{array}$ & $\begin{array}{l}-0.001 \\
(0.005)\end{array}$ & $\begin{array}{l}-0.000 \\
(0.002)\end{array}$ \\
\hline Construction & $\begin{array}{l}-0.001 \\
(0.002)\end{array}$ & $\begin{array}{l}-0.000 \\
(0.006)\end{array}$ & $\begin{array}{l}-0.002 \\
(0.002)\end{array}$ & $\begin{array}{l}-0.001 \\
(0.004)\end{array}$ & $\begin{array}{l}-0.003 \\
(0.005)\end{array}$ & $\begin{array}{l}-0.002 \\
(0.004)\end{array}$ \\
\hline Manufacturing & $\begin{array}{l}-0.000 \\
(0.001)\end{array}$ & $\begin{array}{c}0.002 \\
(0.003)\end{array}$ & $\begin{array}{l}-0.001 \\
(0.002)\end{array}$ & $\begin{array}{l}-0.001 \\
(0.002)\end{array}$ & $\begin{array}{l}-0.004 \\
(0.004)\end{array}$ & $\begin{array}{l}-0.002 \\
(0.002)\end{array}$ \\
\hline Transportation & $\begin{array}{c}-0.001 \\
(0.003)\end{array}$ & $\begin{array}{l}-0.004 \\
(0.009)\end{array}$ & $\begin{array}{c}0.004 \\
(0.005)\end{array}$ & $\begin{array}{l}-0.000 \\
(0.007)\end{array}$ & $\begin{array}{c}0.005 \\
(0.012)\end{array}$ & $\begin{array}{c}0.001 \\
(0.006)\end{array}$ \\
\hline Trade & $\begin{array}{l}-0.000 \\
(0.003)\end{array}$ & $\begin{array}{c}0.006 \\
(0.007)\end{array}$ & $\begin{array}{c}0.001 \\
(0.004)\end{array}$ & $\begin{array}{l}-0.001 \\
(0.004)\end{array}$ & $\begin{array}{l}-0.007 \\
(0.008)\end{array}$ & $\begin{array}{l}-0.000 \\
(0.004)\end{array}$ \\
\hline Finance & $\begin{array}{c}-0.004 * * * \\
(0.001)\end{array}$ & $\begin{array}{c}0.000 \\
(0.003)\end{array}$ & $\begin{array}{c}-0.006^{* * *} \\
(0.002)\end{array}$ & $\begin{array}{l}-0.003 \\
(0.002)\end{array}$ & $\begin{array}{l}-0.005 \\
(0.004)\end{array}$ & $\begin{array}{c}-0.004^{* *} \\
(0.002)\end{array}$ \\
\hline Service & $\begin{array}{l}-0.001 \\
(0.003)\end{array}$ & $\begin{array}{c}0.009 \\
(0.006)\end{array}$ & $\begin{array}{l}-0.002 \\
(0.003)\end{array}$ & $\begin{array}{l}-0.000 \\
(0.002)\end{array}$ & $\begin{array}{c}0.001 \\
(0.006)\end{array}$ & $\begin{array}{l}-0.002 \\
(0.002)\end{array}$ \\
\hline Government & $\begin{array}{c}0.001 \\
(0.002)\end{array}$ & $\begin{array}{c}0.003 \\
(0.004)\end{array}$ & $\begin{array}{c}0.001 \\
(0.002)\end{array}$ & $\begin{array}{l}-0.004 \\
(0.003)\end{array}$ & $\begin{array}{l}-0.005 \\
(0.004)\end{array}$ & $\begin{array}{l}-0.003 \\
(0.003)\end{array}$ \\
\hline Concentration & $\begin{array}{c}0.008 * * * \\
(0.002)\end{array}$ & $\begin{array}{c}0.003 \\
(0.005)\end{array}$ & $\begin{array}{c}0.005^{* *} \\
(0.002)\end{array}$ & $\begin{array}{c}0.005^{* *} \\
(0.003)\end{array}$ & $\begin{array}{c}0.006 \\
(0.006)\end{array}$ & $\begin{array}{l}0.004 * \\
(0.002)\end{array}$ \\
\hline Gross Product & $\begin{array}{c}-0.000^{* *} \\
(0.000)\end{array}$ & $\begin{array}{l}-0.000 \\
(0.000)\end{array}$ & $\begin{array}{c}-0.000 * * \\
(0.000)\end{array}$ & $\begin{array}{l}-0.000 \\
(0.000)\end{array}$ & $\begin{array}{l}-0.000 \\
(0.000)\end{array}$ & $\begin{array}{l}-0.000 \\
(0.000)\end{array}$ \\
\hline Intra & $\begin{array}{l}-0.006 \\
(0.006)\end{array}$ & $\begin{array}{c}0.002 \\
(0.013)\end{array}$ & $\begin{array}{l}-0.008 \\
(0.006)\end{array}$ & $\begin{array}{c}0.004 \\
(0.007)\end{array}$ & $\begin{array}{c}0.019 \\
(0.013)\end{array}$ & $\begin{array}{c}0.004 \\
(0.006)\end{array}$ \\
\hline Inter & $\begin{array}{l}-0.001 \\
(0.008)\end{array}$ & $\begin{array}{l}-0.010 \\
(0.015)\end{array}$ & $\begin{array}{l}-0.005 \\
(0.008)\end{array}$ & $\begin{array}{l}-0.006 \\
(0.007)\end{array}$ & $\begin{array}{c}0.000 \\
(0.014)\end{array}$ & $\begin{array}{c}-0.014 * \\
(0.008)\end{array}$ \\
\hline Constant & $\begin{array}{c}0.313^{* * *} \\
(0.097)\end{array}$ & $\begin{array}{c}0.086 \\
(0.184)\end{array}$ & $\begin{array}{c}0.278^{* *} \\
(0.122)\end{array}$ & $\begin{array}{c}0.192 \\
(0.145)\end{array}$ & $\begin{array}{c}0.235 \\
(0.234)\end{array}$ & $\begin{array}{c}0.182 \\
(0.138)\end{array}$ \\
\hline State FE & Yes & Yes & Yes & Yes & Yes & Yes \\
\hline Year FE & Yes & Yes & Yes & Yes & Yes & Yes \\
\hline Observations & 1,417 & 1,312 & 1,414 & 1,418 & 1,324 & 1,417 \\
\hline Adjusted $\mathrm{R}^{2}$ & 0.913 & 0.802 & 0.893 & 0.895 & 0.725 & 0.901 \\
\hline
\end{tabular}




\section{Table 3}

Endogeneity tests

This table reports OLS regression estimates of Eq. (2). We truncate the state-year panel to a $+/-10$ year window around deregulatory events. Definitions of variables are in the Appendix. Robust standard errors clustered by year are reported in parenthesis. Significance at the 1\%, 5\%, and $10 \%$ level is indicated by $* * *, * *$, and *, respectively.

\begin{tabular}{|c|c|c|c|c|c|c|}
\hline & \multicolumn{3}{|c|}{ LnPat } & \multicolumn{3}{|c|}{ LnCite } \\
\hline & $\begin{array}{c}\text { Total } \\
(1)\end{array}$ & $\begin{array}{c}\text { Public } \\
(2)\end{array}$ & $\begin{array}{c}\text { Private } \\
\text { (3) }\end{array}$ & $\begin{array}{c}\text { Total } \\
(4)\end{array}$ & $\begin{array}{c}\text { Public } \\
(5)\end{array}$ & $\begin{array}{c}\text { Private } \\
\text { (6) }\end{array}$ \\
\hline \multirow[t]{2}{*}{ Before $^{2+}$} & 0.033 & 0.060 & -0.006 & 0.014 & -0.026 & 0.066 \\
\hline & $(0.058)$ & $(0.037)$ & $(0.052)$ & $(0.035)$ & $(0.073)$ & $(0.047)$ \\
\hline \multirow[t]{2}{*}{ Before $^{1}$} & -0.103 & -0.031 & -0.111 & -0.067 & -0.094 & -0.019 \\
\hline & $(0.095)$ & $(0.032)$ & $(0.089)$ & $(0.057)$ & $(0.131)$ & $(0.073)$ \\
\hline \multirow[t]{2}{*}{ After $^{1}$} & $-0.086 *$ & $-0.081 * *$ & -0.063 & -0.028 & -0.056 & 0.001 \\
\hline & $(0.050)$ & $(0.030)$ & $(0.049)$ & $(0.049)$ & $(0.124)$ & $(0.036)$ \\
\hline \multirow[t]{2}{*}{ After $^{2+}$} & $-0.130 *$ & $-0.091 * * *$ & -0.100 & $-0.075^{* *}$ & $-0.169 *$ & -0.045 \\
\hline & $(0.070)$ & $(0.029)$ & $(0.065)$ & $(0.031)$ & $(0.083)$ & $(0.040)$ \\
\hline \multirow[t]{2}{*}{ Constant } & $0.627 * * *$ & $0.573 * * *$ & 0.012 & $2.351 * * *$ & $2.432 * * *$ & -0.132 \\
\hline & $(0.117)$ & $(0.075)$ & $(0.105)$ & $(0.070)$ & $(0.146)$ & $(0.095)$ \\
\hline State FE & Yes & Yes & Yes & Yes & Yes & Yes \\
\hline Year FE & Yes & Yes & Yes & Yes & Yes & Yes \\
\hline Observations & 910 & 910 & 910 & 910 & 910 & 910 \\
\hline Adjusted $\mathrm{R}^{2}$ & 0.936 & 0.925 & 0.924 & 0.940 & 0.893 & 0.937 \\
\hline
\end{tabular}




\section{Table 4}

Randomization of deregulations

This table reports OLS regression estimates of Eqs. (1a) and (1b) with randomized state deregulations. The dependent variable in columns (1) - (3) is the natural logarithm of one plus the sum of the patents generated in the next three years. The dependent variable in column (4) (6) is the natural logarithm of one plus the number of citations for patents generated in the next three years. Definitions of control variables are in the Appendix. Robust standard errors clustered by year are reported in parenthesis. Significance at the $1 \%, 5 \%$, and $10 \%$ level is indicated by $* * *, * *$, and *, respectively.

\begin{tabular}{|c|c|c|c|c|c|c|}
\hline & \multicolumn{3}{|c|}{ LnPat } & \multicolumn{3}{|c|}{ LnCite } \\
\hline & $\begin{array}{c}\text { Total } \\
(1)\end{array}$ & $\begin{array}{c}\text { Public } \\
(2)\end{array}$ & $\begin{array}{c}\text { Private } \\
\text { (3) }\end{array}$ & $\begin{array}{c}\text { Total } \\
(4)\end{array}$ & $\begin{array}{c}\text { Public } \\
(5)\end{array}$ & $\begin{array}{c}\text { Private } \\
\text { (6) }\end{array}$ \\
\hline \multirow[t]{2}{*}{ RSindex } & 0.002 & -0.028 & 0.020 & -0.007 & -0.091 & 0.019 \\
\hline & $(0.038)$ & $(0.070)$ & $(0.027)$ & $(0.041)$ & $(0.095)$ & $(0.033)$ \\
\hline \multirow[t]{2}{*}{ Mining } & 0.011 & 0.030 & 0.001 & 0.012 & $0.098^{*}$ & -0.000 \\
\hline & $(0.032)$ & $(0.048)$ & $(0.027)$ & $(0.033)$ & $(0.053)$ & $(0.028)$ \\
\hline \multirow[t]{2}{*}{ Construction } & -0.009 & 0.059 & -0.027 & -0.002 & 0.118 & -0.022 \\
\hline & $(0.037)$ & $(0.068)$ & $(0.023)$ & $(0.043)$ & $(0.080)$ & $(0.033)$ \\
\hline \multirow[t]{2}{*}{ Manufacturing } & 0.017 & 0.025 & 0.000 & 0.015 & 0.076 & 0.001 \\
\hline & $(0.026)$ & $(0.044)$ & $(0.023)$ & $(0.028)$ & $(0.054)$ & $(0.023)$ \\
\hline \multirow[t]{2}{*}{ Transportation } & -0.069 & -0.144 & -0.037 & -0.086 & -0.190 & -0.046 \\
\hline & $(0.068)$ & $(0.151)$ & $(0.038)$ & $(0.072)$ & $(0.214)$ & $(0.041)$ \\
\hline \multirow[t]{2}{*}{ Trade } & $0.130 * *$ & 0.126 & $0.093 * *$ & $0.131^{*}$ & 0.177 & 0.082 \\
\hline & $(0.061)$ & (0.109) & $(0.041)$ & $(0.072)$ & $(0.137)$ & $(0.054)$ \\
\hline \multirow[t]{2}{*}{ Finance } & -0.004 & -0.025 & $0.047^{*}$ & -0.016 & -0.004 & 0.037 \\
\hline & $(0.028)$ & $(0.046)$ & $(0.027)$ & $(0.028)$ & $(0.058)$ & $(0.026)$ \\
\hline \multirow[t]{2}{*}{ Service } & $-0.101^{* * *}$ & $-0.117^{*}$ & $-0.088 * *$ & $-0.112 * *$ & -0.067 & $-0.112 * * *$ \\
\hline & $(0.038)$ & $(0.067)$ & $(0.038)$ & $(0.045)$ & $(0.084)$ & $(0.041)$ \\
\hline \multirow[t]{2}{*}{ Government } & -0.043 & -0.066 & $-0.057 * *$ & -0.043 & -0.038 & -0.057 \\
\hline & $(0.036)$ & $(0.071)$ & $(0.027)$ & $(0.049)$ & $(0.095)$ & $(0.041)$ \\
\hline \multirow{2}{*}{ Concentration } & 0.009 & 0.084 & -0.026 & 0.014 & 0.066 & -0.040 \\
\hline & $(0.042)$ & $(0.067)$ & $(0.033)$ & $(0.046)$ & $(0.088)$ & $(0.037)$ \\
\hline \multirow[t]{2}{*}{ Gross Product } & -0.000 & -0.000 & 0.000 & 0.000 & -0.000 & 0.000 \\
\hline & $(0.000)$ & $(0.000)$ & $(0.000)$ & $(0.000)$ & $(0.000)$ & $(0.000)$ \\
\hline \multirow[t]{2}{*}{ Intra } & -0.200 & -0.373 & -0.044 & -0.235 & -0.465 & -0.081 \\
\hline & $(0.123)$ & $(0.246)$ & $(0.061)$ & (0.163) & $(0.325)$ & $(0.100)$ \\
\hline \multirow[t]{2}{*}{ Inter } & -0.068 & -0.052 & -0.032 & $-0.147 * * *$ & -0.207 & -0.074 \\
\hline & $(0.043)$ & $(0.096)$ & $(0.068)$ & $(0.047)$ & $(0.134)$ & $(0.096)$ \\
\hline \multirow[t]{2}{*}{ Constant } & $10.433 * * *$ & 8.331* & $10.781 * * *$ & $9.013 * * *$ & 4.421 & $10.252 * * *$ \\
\hline & (2.298) & (4.939) & (1.429) & $(2.674)$ & $(6.466)$ & (1.755) \\
\hline State FE & Yes & Yes & Yes & Yes & Yes & Yes \\
\hline Year FE & Yes & Yes & Yes & Yes & Yes & Yes \\
\hline Observations & 1,426 & 1,426 & 1,426 & 1,426 & 1,426 & 1,426 \\
\hline Adjusted $\mathrm{R}^{2}$ & 0.966 & 0.926 & 0.971 & 0.954 & 0.901 & 0.954 \\
\hline
\end{tabular}




\section{Table 5}

External financial dependence

This table reports OLS regression estimates of Eq. (3). We consider companies with EFD values above the median EFD (Dependence $=0$ ) in year $\mathrm{t}$ to be financially dependent. Definitions of control variables are in the Appendix. Robust standard errors clustered by year are reported in parenthesis. Significance at the $1 \%, 5 \%$, and $10 \%$ level is indicated by $* * *$, **, and * respectively.

\begin{tabular}{lccccc}
\hline & \multicolumn{2}{c}{ Private Firms } & & \multicolumn{2}{c}{ Public Corporations } \\
\cline { 2 - 3 } \cline { 5 - 6 } & LnPat & LnCite & & LnPat & LnCite \\
& $(1)$ & $(2)$ & & $(3)$ & $(4)$ \\
\hline \multirow{2}{*}{ RSindex } & & & & & \\
& $\left(0.019^{* * *}\right.$ & $-0.016^{* *}$ & & -0.021 & -0.060 \\
Dependence & $(0.003)$ & $(0.007)$ & & $(0.029)$ & $(0.047)$ \\
& $(0.013)$ & $(0.028)$ & & $(0.232)$ & $(0.307)$ \\
RSindex $\times$ Dependence & $0.046^{* * *}$ & $0.049^{* * *}$ & & $0.136^{* *}$ & $0.194^{* *}$ \\
& $(0.004)$ & $(0.007)$ & & $(0.062)$ & $(0.094)$ \\
Constant & $1.256^{* * *}$ & $2.749^{* * *}$ & & $0.256^{* *}$ & $0.347^{* *}$ \\
& $(0.134)$ & $(0.361)$ & & $(0.112)$ & $(0.166)$ \\
Controls & Yes & Yes & & Yes & Yes \\
State FE & Yes & Yes & & Yes & Yes \\
Year FE & Yes & Yes & & Yes & Yes \\
Industry FE & Yes & Yes & & Yes & Yes \\
Observations & 223,655 & 223,655 & & 76,015 & 76,015 \\
Adjusted R $\mathrm{R}^{2}$ & 0.199 & 0.085 & & 0.129 & 0.154 \\
\hline
\end{tabular}




\section{Table 6}

External financial dependence with alternative proxies: Assets, Age, Bank-dependence and SA index

This table reports OLS regression estimates of Eq. (3). Panel A defines companies with asset values below the median asset value in year $t$ as financially dependent (Dependence $=0$ ). Panel B defines companies with age below the median age value in year $t$ as financially dependent (Dependence $=0$ ). Panel C defines companies with accumulative bank loans (both in-state and out-of-state) above the median accumulative bank loans in year $t$ as financially dependent (Dependence $=0)$. Panel $\mathrm{D}$ defines companies with SA index below the median SA index in year $t$ as financially dependent (Dependence $=0$ ), where SA index $=-0.737 \times \operatorname{Ln}($ assets) +0.043 $\times$ Ln (assets) ${ }^{2}-0.04 \times$ age.) Definitions of control variables are in the Appendix. Robust standard errors clustered by year are reported in parenthesis. Significance at the $1 \%, 5 \%$, and $10 \%$ level is indicated by $* * *, * *$, and $*$ respectively.

\begin{tabular}{|c|c|c|c|c|c|c|c|c|}
\hline & \multicolumn{2}{|c|}{$\begin{array}{l}\text { Panel A } \\
\text { Assets }\end{array}$} & \multicolumn{2}{|c|}{$\begin{array}{l}\text { Panel B } \\
\text { Age }\end{array}$} & \multicolumn{2}{|c|}{$\begin{array}{c}\text { Panel C } \\
\text { Bank dependence }\end{array}$} & \multicolumn{2}{|c|}{$\begin{array}{l}\text { Panel D } \\
\text { SA index }\end{array}$} \\
\hline & $\begin{array}{l}\text { LnPat } \\
\text { (1) }\end{array}$ & $\begin{array}{l}\text { LnCite } \\
\text { (2) }\end{array}$ & $\begin{array}{l}\text { LnPat } \\
\text { (3) }\end{array}$ & $\begin{array}{l}\text { LnCite } \\
\text { (4) }\end{array}$ & $\begin{array}{l}\text { LnPat } \\
\text { (5) }\end{array}$ & $\begin{array}{l}\text { LnCite } \\
(6)\end{array}$ & $\begin{array}{l}\text { LnPat } \\
(7)\end{array}$ & $\begin{array}{l}\text { LnCite } \\
\text { (8) }\end{array}$ \\
\hline RSindex & $\begin{array}{c}-0.009 * * * \\
(0.003)\end{array}$ & $\begin{array}{c}-0.017^{* *} \\
(0.007)\end{array}$ & $\begin{array}{c}-0.012 * * \\
(0.006)\end{array}$ & $\begin{array}{c}0.004 \\
(0.012)\end{array}$ & $\begin{array}{c}-0.018 * * * \\
(0.003)\end{array}$ & $\begin{array}{c}-0.033 * * * \\
(0.008)\end{array}$ & $\begin{array}{c}-0.012 * * * \\
(0.004)\end{array}$ & $\begin{array}{c}0.004 \\
(0.007)\end{array}$ \\
\hline Dependence & $\begin{array}{c}-0.288 * * * \\
(0.013)\end{array}$ & $\begin{array}{c}-0.517^{* * *} \\
(0.027)\end{array}$ & $\begin{array}{c}-0.053^{* *} \\
(0.026)\end{array}$ & $\begin{array}{c}0.043 \\
(0.065)\end{array}$ & $\begin{array}{c}-0.560 * * * \\
(0.030)\end{array}$ & $\begin{array}{c}-1.043 * * * \\
(0.060)\end{array}$ & $\begin{array}{c}-0.064 * * * \\
(0.014)\end{array}$ & $\begin{array}{c}0.019 \\
(0.026)\end{array}$ \\
\hline RSindex $\times$ Dependence & $\begin{array}{c}0.030 * * * \\
(0.003)\end{array}$ & $\begin{array}{c}0.055^{* * * *} \\
(0.007)\end{array}$ & $\begin{array}{c}0.029 * * * \\
(0.007)\end{array}$ & $\begin{array}{c}0.010 \\
(0.017)\end{array}$ & $\begin{array}{c}0.076^{* * * *} \\
(0.017)\end{array}$ & $\begin{array}{c}0.137 * * * \\
(0.035)\end{array}$ & $\begin{array}{c}0.029 * * * \\
(0.004)\end{array}$ & $\begin{array}{l}0.012 * \\
(0.007)\end{array}$ \\
\hline Constant & $\begin{array}{c}1.263^{* * * *} \\
(0.143)\end{array}$ & $\begin{array}{c}2.795^{* * * *} \\
(0.364)\end{array}$ & $\begin{array}{c}1.198 * * * \\
(0.210)\end{array}$ & $\begin{array}{c}2.586 * * * \\
(0.733)\end{array}$ & $\begin{array}{c}1.464 * * * \\
(0.149)\end{array}$ & $\begin{array}{c}3.191^{* * *} \\
(0.399)\end{array}$ & $\begin{array}{c}1.201^{* * *} \\
(0.135)\end{array}$ & $\begin{array}{c}2.609 * * * \\
(0.358)\end{array}$ \\
\hline Controls & Yes & Yes & Yes & Yes & Yes & Yes & Yes & Yes \\
\hline State FE & Yes & Yes & Yes & Yes & Yes & Yes & Yes & Yes \\
\hline Year FE & Yes & Yes & Yes & Yes & Yes & Yes & Yes & Yes \\
\hline Industry FE & Yes & Yes & Yes & Yes & Yes & Yes & Yes & Yes \\
\hline Observations & 223,655 & 223,655 & 223,655 & 223,655 & 223,655 & 223,655 & 223,655 & 223,655 \\
\hline Adjusted $\mathrm{R}^{2}$ & 0.205 & 0.089 & 0.198 & 0.084 & 0.211 & 0.094 & 0.198 & 0.072 \\
\hline
\end{tabular}




\section{Table 7}

Banking relationships

This table reports OLS regression estimates of Eq. (4). Panel A shows the results for private firms and Panel B shows the results for public corporations. BankLoans is an indicator taking a value of one if the cumulative dollar value of loans borrowed by company $i$ up to year $t$ is greater than the median in that year. We set cumulative loans to zero for companies that do not have any bank loans prior to the passage of any legislation enforcing IBBEA changes in the companies' headquarters states. In column (1) - (2) we consider only the loans borrowed by company $i$ by banks located in the same state as company $i$ 's headquarters. In column (3) - (4) we consider only the loans borrowed by company $i$ from banks outside company $i$ 's headquarter state. Definitions of control variables are in the Appendix. Robust standard errors clustered by year are reported in parenthesis. Significance at the $1 \%, 5 \%$, and $10 \%$ level is indicated by $* * *$, **, and *, respectively.

Panel A: Private firms

\begin{tabular}{lccccc}
\hline & \multicolumn{2}{c}{ In-State } & & \multicolumn{2}{c}{ Out-of-State } \\
\cline { 2 - 3 } \cline { 5 - 6 } & LnPat & LnCite & & LnPat & LnCite \\
& $(1)$ & $(2)$ & & $(3)$ & $(4)$ \\
\hline RSindex & -0.003 & 0.002 & & $-0.021^{* * *}$ & $-0.040^{* * *}$ \\
& $(0.002)$ & $(0.007)$ & & $(0.003)$ & $(0.008)$ \\
BankLoans & $-0.381^{* * *}$ & $-0.652^{* * *}$ & & $-0.561^{* * *}$ & $-1.050^{* * *}$ \\
& $(0.020)$ & $(0.056)$ & & $(0.031)$ & $(0.061)$ \\
RSindex $\times$ BankLoans & $0.036^{* * *}$ & 0.038 & & $0.079^{* * *}$ & $0.148^{* * *}$ \\
& $(0.011)$ & $(0.025)$ & & $(0.016)$ & $(0.033)$ \\
Constant & $1.377^{* * *}$ & $3.038^{* * *}$ & & $1.465^{* * *}$ & $3.179^{* * *}$ \\
& $(0.145)$ & $(0.386)$ & & $(0.147)$ & $(0.394)$ \\
Controls & Yes & Yes & & Yes & Yes \\
State FE & Yes & Yes & & Yes & Yes \\
Year FE & Yes & Yes & & Yes & Yes \\
Industry FE & Yes & Yes & & Yes & Yes \\
Observations & 223,655 & 223,655 & & 223,655 & 223,655 \\
Adjusted R ${ }^{2}$ & 0.207 & 0.092 & & 0.211 & 0.094 \\
\hline
\end{tabular}


Panel B: Public corporations

\begin{tabular}{lccccc}
\hline & \multicolumn{2}{c}{ In-State } & & \multicolumn{2}{c}{ Out-of-State } \\
\cline { 2 - 3 } \cline { 5 - 6 } & LnPat & LnCite & & LnPat & LnCite \\
& $(1)$ & $(2)$ & & & $(3)$ \\
RSindex & 0.020 & 0.009 & & 0.009 & -0.020 \\
& $(0.017)$ & $(0.032)$ & & $(0.015)$ & $(0.021)$ \\
BankLoans & $-0.130^{*}$ & $-0.184^{*}$ & & $-0.745^{* * *}$ & $-1.077^{* * *}$ \\
& $(0.073)$ & $(0.104)$ & & $(0.040)$ & $(0.087)$ \\
RSindex $\times$ BankLoans & 0.028 & 0.036 & & $0.050^{* * *}$ & $0.085^{* * *}$ \\
& $(0.021)$ & $(0.032)$ & & $(0.011)$ & $(0.022)$ \\
Constant & $1.019 * * *$ & $2.428^{* * *}$ & & $1.436^{* * *}$ & $3.022^{* * *}$ \\
& $(0.167)$ & $(0.282)$ & & $(0.162)$ & $(0.269)$ \\
Controls & Yes & Yes & & Yes & Yes \\
State FE & Yes & Yes & & Yes & Yes \\
Year FE & Yes & Yes & & Yes & Yes \\
Industry FE & Yes & Yes & & Yes & Yes \\
Observations & 44,702 & 44,702 & & 44,702 & 44,702 \\
Adjusted R ${ }^{2}$ & 0.130 & 0.162 & & 0.148 & 0.173 \\
\hline
\end{tabular}




\section{Table 8}

Dollar volume of acquisitions.

This table reports OLS regression estimates from Eq. (5) using the natural logarithm of one plus the sum of the patents generated in the next three years as the dependent variable. The acquisition measure, Acquisition, for column (1) is the dollar volume spent on acquisitions for corporation $i$ in year $t$, divided by the corporation's total assets in year $t$. In column (2) Acquisition is the number of acquisitions made by corporation $i$ in year $t$. In column (3) Acquisition is the dollar volume spent on acquisitions for corporation $i$ in year $t$ divided by total assets of corporation $i$ in year $t$ and the number of acquisitions made by corporation $i$ in year $t$. We de-mean both RSindex and the Acquisition measures for ease of interpretation. Definitions of control variables are in the Appendix. Robust standard errors clustered by year are reported in parenthesis. Significance at the $1 \%, 5 \%$, and $10 \%$ level is indicated by $* * *$, **, and *, respectively.

\begin{tabular}{lccc}
\hline & Dollar Volume & Number of Deals & Dollar per Deal \\
& $(1)$ & $(2)$ & $(3)$ \\
\hline RSindex & $0.008^{*}$ & 0.007 & $0.008^{*}$ \\
& $(0.004)$ & $(0.004)$ & $(0.004)$ \\
Acquisition & 0.008 & $0.115^{* * *}$ & -0.000 \\
& $(0.014)$ & $(0.020)$ & $(0.016)$ \\
Acquisition $\times$ RSindex & $0.040^{* *}$ & 0.015 & $0.044^{* *}$ \\
& $(0.018)$ & $(0.010)$ & $(0.021)$ \\
Constant & $-2.259^{* * *}$ & $-2.263^{* * *}$ & $-2.258^{* * *}$ \\
& $(0.071)$ & $(0.072)$ & $(0.071)$ \\
Controls & Yes & Yes & Yes \\
State FE & Yes & Yes & Yes \\
Year FE & Yes & Yes & Yes \\
Industry FE & Yes & Yes & 72,093 \\
Observations & 72,093 & 72,093 & 0.420 \\
Adjusted R ${ }^{2}$ & 0.420 & 0.421 & \\
\hline
\end{tabular}




\section{Table 9}

Patents from acquisition targets

This table reports zero inflated negative binomial marginal effect estimates from Eq. (6). The dependent variable in column (1) is TargetCount, which we calculate in two steps. First, we calculate the sum of all patents generated by a target during the 1976-2006 sample. Then we sum the number of patents acquired by all the targets of corporation $i$ in the year that the targets are acquired. In column (2) the dependent variable is TargetCountPerAcq, which is TargetCount divided by the number of targets corporation $i$ acquires in year $t$. RegChg is a dummy variable set to one in the year of (and all years following) a regulation change. We repeat the observations of states with multiple regulation changes for each regulation change. We de-mean the independent variables (including the year fixed effects). Significance at the $1 \%, 5 \%$, and $10 \%$ level is indicated by $* * *, * *$, and $*$, respectively.

\begin{tabular}{lcc}
\hline & TargetCount & TargetCountPerAcq \\
& $(1)$ & $-0.056^{* *}$ \\
\hline RegChg & $-0.070^{*}$ & $(0.028)$ \\
& $(0.036)$ & Yes \\
Controls & Yes & Yes \\
Year FE & Yes & Yes \\
Firm FE & Yes & 151,883 \\
Observations & 151,883 & \\
\hline
\end{tabular}

